\title{
Lewis Acid Catalysis in the Oxidative Cycloaddition of Thiophenes $^{1}$
}

\author{
Yuanqiang Li, ${ }^{\dagger}$ Thies Thiemann,,,$\neq, \S$ Tsuyoshi Sawada, ${ }^{\ddagger}$ Shuntaro Mataka, ${ }^{\ddagger}$ and \\ Masashi Tashiro*,‡ \\ Graduate School of Engineering Sciences, Kyushu University, 6-1, Kasuga-koh-en, Kasuga-shi, \\ Fukuoka 816, J apan, and Institute of Advanced Material Study, Kyushu University, Fukuoka 816, \\ J apan, and Lab. de Quimica Farmaceutica, Faculdade de Farmacia, Universidade de Coimbra, \\ 3000 Coimbra, Portugal
}

Received October 22, 1996 (Revised Manuscript Received J uly 25, 1997)

\begin{abstract}
Thiophenes 1 were treated with m-chloroperbenzoic acid (m-CPBA) under $\mathrm{BF}_{3} \cdot \mathrm{Et}_{2} \mathrm{O}$ catalysis to afford thiopheneS-monoxides. These could be reacted in situ as intermediary species with a number of dienophiles to provide arenes (with alkynes as dienophiles) or 7-thiabicyclo[2.2.1]hept-2-ene 7-oxides (with alkenes as dienophiles). It was also possible to isolate thiophene S-monoxides in solution and to cycloadd them in a second step. In either way it could be shown that the use of $\mathrm{BF}_{3} \cdot \mathrm{Et}_{2} \mathrm{O}$ enhances the yiel ds of the oxidative cycloaddition of thiophenes considerably. Moreover a greater variety of dienophiles $(\mathbf{2 9 a}, \mathbf{2 9 b}, \mathbf{2 9 c})$ could be reacted with thiophenes than in the case of the noncatalyzed reaction. All cycloadditions catalyzed by $\mathrm{BF}_{3} \cdot \mathrm{Et}_{2} \mathrm{O}$ give only a single diastereoisomer as cycloadduct. The reactions show a high $\pi$-facial sel ectivity, a fact that can be explained by the Cieplak-effect. Without added dienophiles, 2-methylthiophene (1e) gave a single dimer (36) of 2-methylthiophene S-monoxide, whereas 2,5-dimethylthiophene (1a) gave three dimers $(\mathbf{3 2 a}-\mathbf{c})$. In the case of tetrasubstituted thiophenes, thiophene S-monoxides (e.g., 31b and 31c) could be isolated in substance.
\end{abstract}

\section{Introduction}

The Diels-Alder reaction ranks as one of the most extensively researched topics in organic chemistry. It is a very powerful tool in synthesis, as not only two new carbon bonds are formed, but also one or more stereocenters are generated. In fact, in the reaction shown below, five stereocenters are created and controlled. An impressive number of dienes and dienophiles have been studied in the Diels-Alder reaction. Nevertheless, there are still limitations in employing five-membered heterocyclic compounds as dienes in these cycloadditions. This is especially true for the use of thiophenes and its derivatives as diene-components. ${ }^{2}$ Thiophene is known as the least reactive diene of all aromatic five-membered heterocycles. This has been explained by the presence of $\mathbf{3 d}$ orbitals on sulfur which contribute to the resonance stability of the thiophene system. ${ }^{3}$

Where thiophenes are known to undergo the DielsAlder reaction, there are al ways involved limitations as to the substrates (see below: a,b) or special reaction conditions (see below: c,d). ${ }^{4}$ Thus it is known that cycloaddition of thiophenes can occur through one of the following: (a) the use of highly reactive dienophiles such as dicyanoacetylene or arynes; ${ }^{4 a, b}$ (b) a proper choice of substituents on the thiophene, thus enhanced electron-density in the ring system, brought about by the introduction

† Graduate School of Engineering Sciences, Kyushu University.

F Institute of Advanced Material Study, Kyushu University.

$\S$ Universidade de Coimbra.

${ }^{\otimes}$ Abstract published in Advance ACS Abstracts, October 1, 1997.

(1) F or a preliminary communication, see: Li, Y.-Q.; Matsuda, M.; Thiemann, T.; Sawada, T.; Mataka, S.; Tashiro, M. Synlett 1996, 461464.

(2) (a) Katritzky, A. R.; Rees, C. W., Eds., Comprehensive Heterocyclic Chemistry, Vol. 1-8; J ohn Wiley and Sons, New York, 1974; for calculations on thiophene derivatives as dienes, see: (b) J ursic, B. S. Coupe, D. J . Heterocyclic Chem. 1995, 32, 483-489. (c) J ursic, B. S. J . Heterocycl. Chem. 1995, 32, 1445-1455.

(3) (a) Wheland, G. W.; Pauling, L. J . Am. Chem. Soc. 1935, 57, 2086-2095. (b) Lert, P. W.; Trindle, C. J . Am. Chem. Soc. 1971, 93, $6392-6395$ of two methoxy groups at positions 2 and 5, 4 increases the diene-character of the molecule as does the introduction of strain in the thiophene; ${ }^{4 d}$ (c) the use of high reaction temperatures; ${ }^{4 e}$ or $(d)$ the use of high pressure. ${ }^{4 f}$

Thiophenes can be oxidized by m-CPBA to thiopheneS,S-dioxides. ${ }^{5}$ This reaction is known to proceed via intermediate thiophene S-monoxides. Owing to the absence of a lone pair of electrons on sulfur to contribute to the $6 \pi$-system of a potential aromatic system, thiophene $\mathrm{S}, \mathrm{S}$-dioxides have nonaromatic character and behave as cyclic 1,3-dienes. Diels-Alder reactions of 1,2,3,4-tetrachlorothiophene S,S-dioxide are well known with a large variety of dienophiles. ${ }^{5 b, c}$ Nevertheless, in many cases higher reaction temperatures are needed. This is especially true for the much less reactive 2,5-dimethylthiophene S,S-dioxide.

Thiophene S-monoxide possesses one lone pair on sulfur. However, thiophene S-monoxides are known to have nonaromatic character. This has been reported by W. L. Mock ${ }^{6}$ on the basis of the interpretation of the ${ }^{1} \mathrm{H}$ NMR spectrum of 2,5-di-tert-butylthiophene S-monoxide ${ }^{6}$ and the X-ray analysis of dibenzo[b,d]thiophene S-oxide. It could be shown that the sulfur of thiophene Smonoxides is in fact pyramidally configured with the

(4) (a) Helder, R.; Wynberg, H. Tetrahedron Lett. 1972, 605-608. (b) Callander, D. D.; Coe, P. L.; Tatlow, J. C. J . Chem. Soc., Chem. Commun. 1966, 143-144. (c) Barker, J . M.; Huddleston, P. R.; Shutler, S. W. J . Chem. Soc., Perkin Trans. 1 1975, 2483-2484; see also: F. Al-Omran, M. M. A. Khalik, H. Al-Awadhi, M. H. Elnagdi, Tetrahedron 1996, 52, 11915-11928 and ref cited. (d) Nakayama, J .; Kuroda, K. J. Am. Chem. Soc. 1993, 115, 4612-4617. (e) Kuhn, H.J .; Gollnick, K. Tetrahedron Lett. 1972, 1909-1912. (f) Kotsuki, H.; Kitagawa, S.; Nishizawa, H.; Tokoroyama, T.J J Org. Chem. 1978, 43, 1471-1472. Kotsuki, H.; Nishizawa, H.; Kitagawa, S.; Ochi, M.; Yamasaki, N.; Matsuoka, K.; Tokoroyama, T. Bull. Chem. Soc. J pn. 1979, 52, 544548.

(5) Bailey, W. J .; Cummins, E. W. J . Am. Chem. Soc. 1954, 76, 1940-1942. (b) Raasch, M. S. J . Org. Chem. 1980, 45, 856-867. (c) Raasch, M. S. J . Org. Chem. 1980, 45, 867-870. (d) Benders, P. H.; Reinhoudt, D. N.; Trompenaars, W. P. Cycloaddition Reactions of Thiophenes, Thiophene-1-oxides, and Thiophene-1,1-dioxides. In The Chemistry of Heterocyclic Compounds; Gronowitz, S., Ed.; 1985; Vol. $44, \mathrm{p} 713$. 
oxygen as the third ligand located off the mol ecular plane. Later on the structure has been found to be more general by X-ray analyses done by two groups on phenylsubstituted thiophene S-monoxides. ${ }^{7}$ The geometry of the lone pair on sulfur reduces its contribution to any aromaticity of the molecule considerably. Thiophene-Smonoxides are very reactive molecules, ${ }^{8}$ and, although intermediates in the oxidation of thiophenes to thiophene S,S-dioxides, they could not be isolated in such reactions until very recently. The only experimental indication of their presence in these oxidations had been the formation of dimeric cycloadducts between the intermediate sulfoxides and the sulfones ${ }^{9}$ as byproducts. Recently, ${ }^{10}$ however, thiophene S-oxides bearing two bulky substituents at ring positions 2 and 5, such as 2,5-diphenylthiophene S-monoxide or 2,5-bis(trimethylsilyl)thiophene S-oxide could be prepared in low yield under oxidative conditions from the respective thiophenes by $\mathrm{D}$. Mansuy $\left(\mathrm{H}_{2} \mathrm{O}_{2}-\mathrm{CF}_{3} \mathrm{COOH}\right)^{10 \mathrm{~b}}$ and $\mathrm{N}$. Furukawa $\left(\mathrm{BF}_{3} \cdot \mathrm{Et}_{2} \mathrm{O} /\right.$ $\mathrm{m}$-CPBA). ${ }^{10 a}$ The reactivity of these 2,5 -disubstituted thiophene S-oxides has not been reported so far. $\mathrm{K}$. Torssell ${ }^{11}$ and A. G. Fallis ${ }^{12}$ have reported the isolation of 7-thiabicyclo[2.2.1] hept-2-ene 7-oxides as cycloadducts, when 2,5-dimethylthiophene was oxidized by m-CPBA in the presence of electron-poor dienophiles, such as pbenzoquinone and $\mathrm{N}$-phenylmaleimide. The isolated yields of the cycloadducts, however, were low (10-30\%), under the conditions used.

The authors ${ }^{13}$ have utilized this reaction to prepare novel crown ethers ${ }^{13 a}$ and cyclophanes ${ }^{13 c}$ at room temperature from thiopheno crown ethers and thiophenophanes. Also the intramol ecular cyd oaddition of thiophene derivatives using this reaction has been investigated. ${ }^{14}$ While the use of alkynes as dienophiles leads directly to arenes, thiabicyclo[2.2.1] hept-2-ene 7-oxides, formed by the oxidative cycloaddition of thiophenes with alkenes, could easily be transformed to arenes by oxidative SOextrusion (thermolytically, ${ }^{13 c}$ photochemically, ${ }^{13 b}$ el ectrochemically, ${ }^{15}$ or by using $\mathrm{KMnO}_{4}$ under PTC-conditions ${ }^{13 a, c}$ ) or to cyclic dienes by reaction of the primary cycloadducts with $\mathrm{Bu}_{3} \mathrm{SnH} .{ }^{13 b} \mathrm{~A}$ general drawback of the reaction has remained the poor yield and limited choice of dienophiles. In the present paper we report a modified synthetic procedure, using $\mathrm{BF}_{3} \mathrm{Et}_{2} \mathrm{O}$ as a Lewis acid catalyst in the

(6) Mock, W. L. J . Am. Chem. Soc. 1970, 92, 7610-7612.

(7) (a) Pouzet, P.; Erdelmeier, I.; Ginderow, P.; Mornon, J. P.; Dansette, D. M.; Mansuy, D. J . Chem. Soc., Chem. Commun. 1995, 473-474. (b) Meier-Brocks, F.; Weiss, E.J . Organomet. Chem. 1993 453, 33-45.

(8) For calculations on thiophene-S-monoxide, see ref $2 \mathrm{c}$ and (a) Hashmall, J . A.; Horak, V.; Khoo, L. E.; Quicksall, C. O.; Sun, M. K. J. Am. Chem. Soc. 1981, 103, 289-295. (b) I. Rozas, J. Phys. Org. Chem. 1992, 5, 74-82.

(9) Garbish, E. W.; Sprecher, R. F. J . Am. Chem. Soc. 1969, 91, $6785-6800$

(10) (a) Higaki, M.; Furukawa, N. Book of Abstracts, 24th Congress of Heterocyclic Chemistry, Osaka, J apan, 1993; p 277. (b) Erdelmeier, I.; Pouzet, P.; Dansette, D. M.; Ginderow, P.; Mornon, J. P.; Mansuy, D. Book of Abstracts, 16th International Symposium on the Organic Chemistry of Sulfur (ISOCS), Merseburg, 1994; $p 333$; see also ref 7a.

(11) Torssell, K. Acta Chem. Scand. (Ser. B) 1976, 353-357.

(12) Naperstkow, A. M.; Macaulay, J . B.; Newlands, M. J .; Fallis, A. G. Tetrahedron Lett. 1989, 30, 5077-5080.

(13) (a) Li, Y.-Q.; Thiemann, T.; Sawada, T.; Tashiro, M. J . Chem. Soc., Perkin Trans 1 1994, 2323-2329. (b) Thiemann, C.; Thiemann, T.; Li, Y.-Q.; Sawada, T.; Nagano, Y.; Tashiro, M. Bull. Chem. Soc. J pn. 1994, 67, 1886-1893. (c) Thiemann, T.; Li, Y.-Q.; Matsuda, M.; Thiemann, C.; Sawada, T.; Tashiro, M. J . Chem. Soc., Perkin Trans 1, submitted.

(14) Thiemann, T.; Li, Y.-Q.; Mataka, S.; Tashiro, M.J . Chem. Res. (S) 1995, 384; (M) 1995, 2364-2379.

(15) Thiemann, T.; Sá e Melo, L.; Campos Neves, A. S.; Li, Y.-Q.; Tashiro, M.; Geissler, U.; Walton, D. J . Chem. Res., submitted.

\section{Scheme 1}
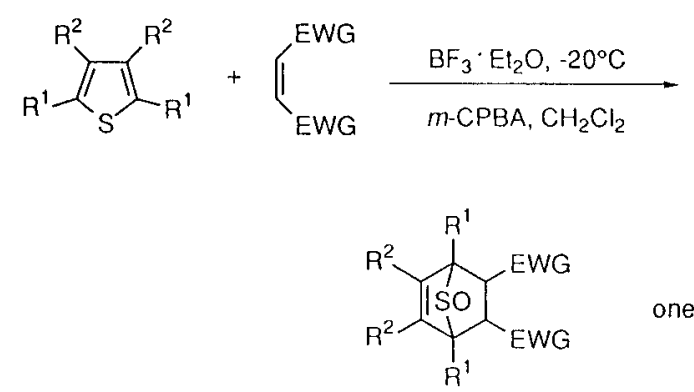

one-pot reaction<smiles>[R7]c1sc([R7]c2ccccc2)c([R7])c1[R]</smiles>

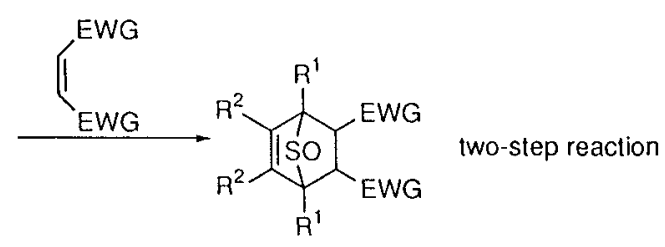

oxidative cycloaddition of thiophenes. It will be shown that the use of $\mathrm{BF}_{3} \cdot \mathrm{Et}_{2} \mathrm{O}$ as Lewis acid catalyst in this reaction greatly improves yields and allows for a large choice of dienophiles.

\section{Results and Discussion}

Lewis acids are widely used to catalyze Diels-Alder reactions. ${ }^{16,17}$ Many Diels-Alder reactions are accelerated by Lewis acid catalysts such as $\mathrm{BF}_{3} \cdot \mathrm{Et}_{2} \mathrm{O}, \mathrm{AlCl}_{3}$, $\mathrm{SnCl}_{4}$, or $\mathrm{ZnCl}_{2}$, and often the application of such catalysts leads to an increase of regio- and stereoselectivity as compared to uncatalyzed reactions. ${ }^{16}$

The reason for using a Lewis acid catalyst in the oxidative cycloaddition of thiophenes is twofold. On the one hand thiophene S-monoxides, formed by the oxidation of thiophenes, readily react with $\mathrm{m}$-CPBA to form thiophene S,S-dioxides. Thiophene S,S-dioxides themselves are stable and do not cycloadd with dienophiles under these conditions (room temperature or below), and thus they are lost for the reaction for all practical purposes. If, however, the thiophene S-monoxide is complexed by a Lewis acid, the sulfur of the sulfoxymoiety is less nud eophilic and is less prone to be oxidized. Thus the thiophene S-monoxides become more stable toward oxidation; a significant shift of the HOMO of the thiophene $\mathrm{S}$-monoxide is not to be expected due to the poor overlap of the p-orbitals and of the lone pair of the sulfoxy-moiety with the diene unit. On the other hand a significant lowering of the LUMO of many dienophiles, such as enones, is known to occur, when a Lewis acid is used as catalyst. Here, the formation and subsequent cycloaddition of thiophene S-monoxides under Lewis acid catalysis were attempted in two ways (Scheme 1). In the first method, which will be designated the "one-pot"

(16) cf., Carruthers, W. Cycloaddition Reactions in Organic Synthesis; Pergamon Press: Oxford, 1990.

(17) cf., (a) Das, J .; Kubela, R.; MacAlpine, G. A.; Stojanic, Z.; Valenta, Z. Can. J . Chem. 1979, 57, 3308-3319. (b) Thiemann, T. Kohlstruk, S.; Schwaer, G.; de Meijere, A. Tetrahedron Lett. 1991, 32, 3483-3486. 


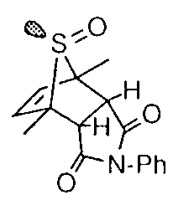

endo

3

Figure 1.

reaction, $\mathrm{m}-\mathrm{CPBA}$ is added to a mixture of the thiophene derivative and the dienophile in the presence of the catalyst at $-20{ }^{\circ} \mathrm{C}$. In the second method, which will be called the "two-step sequence," m-CPBA is added to a mixture of thiophene and catalyst at $-20^{\circ} \mathrm{C}$. After the reaction is over, excess $m$-CPBA, m-chlorobenzoic acid and catalyst are removed from the mixture; thereafter the dienophile is added to the solution of thiophene S-monoxide to give the cycloadduct.

In comparison to the published noncatalyzed reaction 11,12 with yields of $10-30 \%$, the application of $\mathrm{BF}_{3}$. $\mathrm{Et}_{2} \mathrm{O}$ as Lewis acid in the oxidation of thiophenes leads to improved yields of the cycl oadducts of up to $75 \%$. The results of the $\mathrm{BF}_{3} \cdot \mathrm{Et}_{2} \mathrm{O}$-enhanced oxidative cycloaddition of thiophenes are summarized in Table 1 . The use of other Lewis acids such as $\mathrm{AlCl}_{3}$ and $\mathrm{FeCl}_{3}$ in this reaction was not very successful. With highly reactive dienophiles, such as N-phenylmaleimide (2), p-benzoquinone (19), naphthoquinone (15), and others (Table 1, entries $1-5,10-13)$, which are stable under conditions of $\mathrm{BF}_{3}$. $\mathrm{Et}_{2} \mathrm{O} / \mathrm{m}-\mathrm{CPBA}$, both the one-pot and the two-step methods can be used. For the most part the reactions are finished within $3 \mathrm{~h}$ at $-20^{\circ} \mathrm{C}$.

When using tetracyanoethylene (TCNE) (10) as dienophile (entry 7) the two-step method is preferable as the separation of the excess amount of TCNE from cycloadduct $\mathbf{1 1}$ is exceedingly difficult. By the two-step method, the proper amount of TCNE can be added to a solution of 2,5-dimethylthiophene S-oxide (31a) in dichloromethane until the 2,5-dimethylthiophene S-oxide has reacted completely (TLC control).

Biscycloadduct 22 is formed from 2,5-dimethylthiophene S-oxide (31a) and p-benzoquinone (19, entry 14) in the two-step sequence. When the one-pot procedure is used, only the mono-adduct $\mathbf{2 0}$ forms. This agrees with the results found in the noncatalyzed reaction. ${ }^{11}$ In the one-pot procedure a low concentration of the thiophene S-monoxide is maintained throughout the reaction, as the thiophene S-monoxide produced by the slow addition of $\mathrm{m}$-CPBA is used up relatively quickly in the cycloaddition reaction.

As some dienophiles, such as the 1:1 furan-acetylenic ester adducts $\mathbf{2 3}$ and $\mathbf{2 5}$ (entries 15-18), are known to be sensitive ${ }^{18}$ to acidic media in general or m-CPBA in particular, only poor yields of cycloadducts can be isolated in such cases, when the one-pot procedure is used (eg, $5 \%$ or less of the cycloadducts 24 and 26). This limitation of the $\mathrm{BF}_{3} \cdot \mathrm{Et}_{2} \mathrm{O} / \mathrm{m}$-CPBA system can be circumvented by the use of the two-step reaction method, in which thiophene S-monoxide is reacted with the proper amount of dienophile under neutral conditions, and a decomposition of the dienophile is avoided. The two-step method improves the yields of $\mathbf{2 4}, \mathbf{2 6}, \mathbf{2 7}$, and $\mathbf{2 8}$ up to $50 \%$.

Halogen-substituted thiophenes are known to be less readily oxidized to the corresponding thiophene S,Sdioxides than thiophenes with alkyl-substituents. On the other hand tetrachlorothiophene S,S-dioxide is known to be a very reactive diene which reacts with various dienophiles. Under the oxidative reaction conditions presented here in the one-pot method, 2,5-dichlorothiophene and 2,5-dimethyl-3,4-dibromothiophene reacted with dienophiles such as $\mathrm{N}$-phenylmaleimide to give cycloadducts 6 (entry 4) and 7 (entry 5) in low to moderate yields. Reaction times are longer (up to $20 \mathrm{~h}$ ) and the needed reaction temperatures higher $\left(0-25^{\circ} \mathrm{C}\right)$. 2,5-Dibromothiophene and 2,3,4,5-tetrabromothiophene, however, could not be reacted with N-phenylmaleimide at all under the present reaction conditions. Subsequently it could be shown that these halogenated thiophenes can be reacted at even higher temperatures $\left(50^{\circ} \mathrm{C}\right)$ without $\mathrm{BF}_{3^{-}}$ catalysis. ${ }^{15}$ The halogenated thiophene S-monoxides are less prone to be oxidized to thiophene S,S-dioxides and undergo cycloaddition more readily, so that the cycloaddition reaction is able to compete with a further oxidation under noncatalyzed conditions.

All of the above-mentioned cycloadditions give cycloadducts as a single diastereoisomer, and the configuration of the cycloadducts $3^{19}$ (Figure 1), 18a (Figure 2), and 24 (Figure 3) were determined by X-ray diffraction. All the cycloadducts are endo-products, the lone pair on sulfur being on the same side as the newly formed double bond of the cycloadduct. This is in accordance with other adducts formed by the oxidative cycloaddition reaction of thiophenes without Lewis-acid catalysis, where the stereochemistry of the products has been ascertained by X-ray crystal structural analyses both by A. G. Fallis ${ }^{12}$ and by ourselves. ${ }^{13 a, b}$ The endo-selectivity in itself is not surprising, as the low temperature needed for the reaction should favor kinetically-controlled cycloadducts. ${ }^{20}$ Moreover, it has been found that Lewis-acid catalysis usually increases the extent of endo-addition in DielsAlder reactions. ${ }^{21}$ Thus, oxidative cycloaddition of dimethylthiophene with $\mathbf{1 7}$ under Lewis acid catalysis gives only endo-adduct 18a. The uncatalyzed cycloaddition of 2,5-dimethylthiophene with the related dienes 2,3-norboneno-p-benzoquinone (NPBQ) ${ }^{22}$ and norbornano-p-benzoquinone (DNPBQ) gives the corresponding cycloadducts as a mixture of exo- and endo-adducts. ${ }^{23}$

The $\pi$-facial selectivity can be explained by the "Cieplak Effect", 24 an effect first proposed by Cieplak ${ }^{24}$ to account for the directing effects of remote substituents in addition reactions to substituted cyclohexanones (Figure 4). A large number of experimental observations in DielsAlder reactions of dienophiles with 5-substituted cyclopentadienes have shown that the dienophiles will approach anti to the antiperiplanar $\sigma$ bond that is the better donor at 5-position of cyclopentadiene. ${ }^{25}$ This $\sigma$-bond will best stabilize the vacant $\sigma^{*}$-orbital of the incipient

(18) McCulloch, A. W.; Smith, D. G.; Mclnnes, A. G. Can. J . Chem. 1974, 52, 1013-1018.

(19) The X-ray analysis of $\mathbf{3}$ has been performed before; see ref 12 In the case, however, $\mathbf{3}$ was formed in the uncatalyzed reaction.

(20) Although in most Diels-Alder reactions of cyclic dienes the cycloadducts are formed predominantly by endo-addition, there have been many reports of mixtures of endo/exo-products.

(21) This has been discussed in: (a) Houk, K. N.; Strozier, R. W. J. Am. Chem. Soc. 1973, 95, 4904-4096. (b) Alston, P. V.; Ottenbrite, R. M. J . Org. Chem. 1975, 40, 1111-1116. (c) Birney, D. M.; Houk, K. N. J . Am. Chem. Soc. 1990, 112, 4127-4133.

(22) Meinwald, J .; Wiley, G. A. J . Am. Chem. Soc. 1958, 80, 36673671.

(23) F or $\pi$-face selectivity of NPBQ in cycloaddition reactions, see also: Mehta, G.; Padma, S.; Pattabhi, V.; Pramanik, A.; Chandrasekhar, J. J . Am. Chem. Soc. 1990, 112, 2942-2949.

(24) Cieplak, A. S. J. Am. Chem. Soc. 1981, 103, 4540-4552. Cieplak, A. S.; Tait, B. D.; J ohnson, C. R. J . Am. Chem. Soc. 1989, $111,8447-8462$. 
Table 1. Oxidative Diels-Alder Reaction of Thiophenes with Highly Reactive Dienophiles

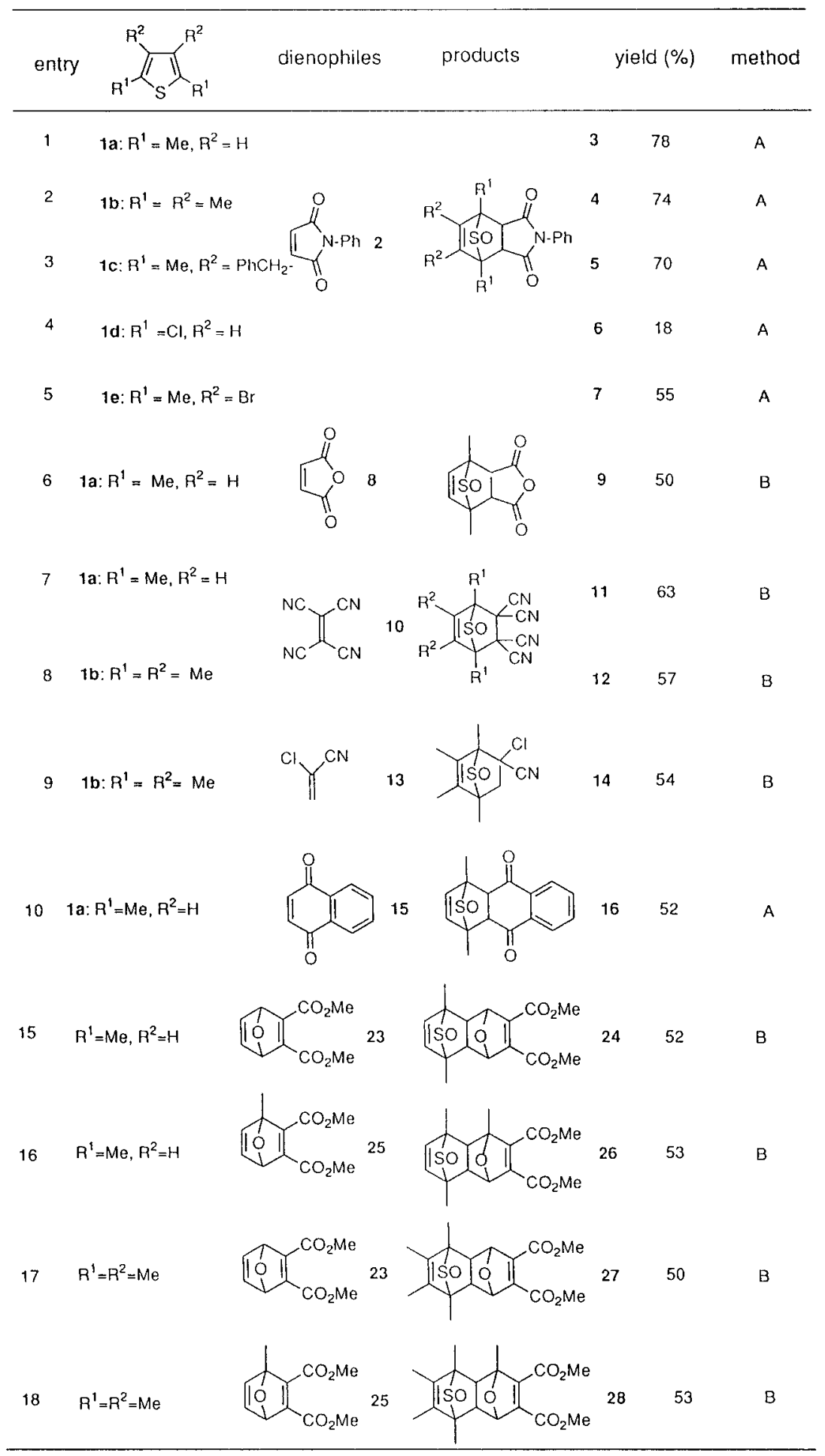

a method A: one-pot reaction; method B: two-step reaction

$\sigma$-bonds formed in the transition state. Cycloadditions to thiophene S-monoxides have been predicted to occur anti to the lone electron-pair on the sulfur, which is the better hyperconjugative donor when compared to the oxygen of the sulfoxy-moiety. The lone-pair electron orbital at the sulfur will stabilize the vacant $\sigma^{*}$-orbitals of the developing incipient $\sigma$-bonds better than would any orbital associated with the oxygen of the sulfoxy moiety (Figure 5). This would be even more so, when the oxygen of the sulfoxy-unit is complexed by $\mathrm{BF}_{3}$.

(25) Macaulay, J . B.; Fallis, A. G. J . Am. Chem. Soc. 1990, 112, $1136-1144$.
Adducts 18a (as mentioned above) and $\mathbf{2 2}$ are the only diastereoisomers formed in the reaction of 2,5-dimethylthiophene S-oxide with dienophiles 17 and 19, whereby the formation of $\mathbf{2 2}$ proceeds via the monoadduct $\mathbf{2 0}$, which itself acts as the dienophile in the second cycloaddition. X-ray crystal structure analyses ${ }^{37}$ show both adducts, 18a and 24, to be of endo-trans-endo-configuration. This is in agreement with results of the double-side addition of p-benzoquinone with cyclopentadiene, which also show the endo-trans-endo-configuration in the cycloadduct because of steric and electronic factors. ${ }^{26} \mathrm{Hydro}-$ genation of 18a with $\mathrm{H}_{2}(\mathrm{Pd} / \mathrm{C})$ gives $\mathbf{1 8 b}$ as the single 


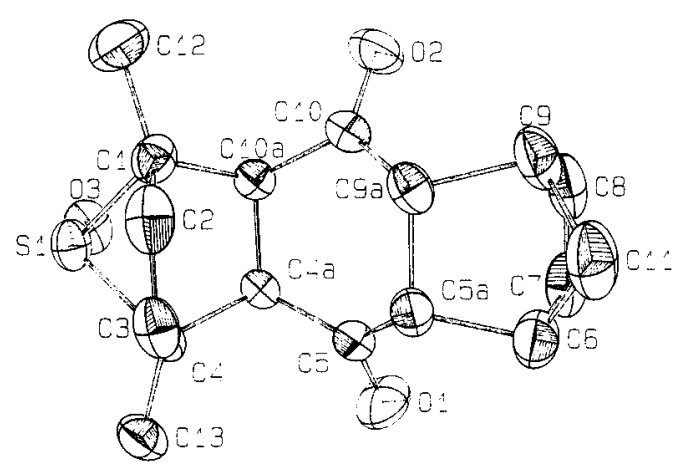

Figure 2. ORTEP structure of $\mathbf{1 8 a}$.

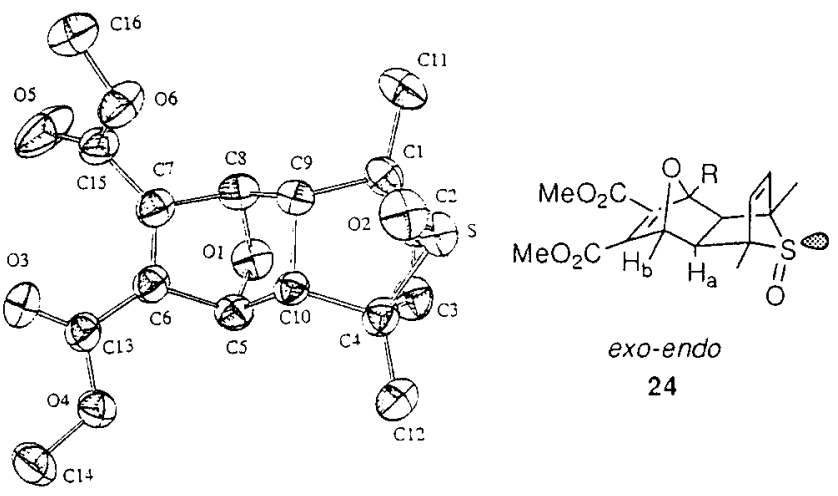

Figure 3. ORTEP structure of cycloadduct 24.

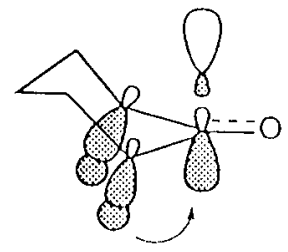

Figure 4. Cieplak effect.

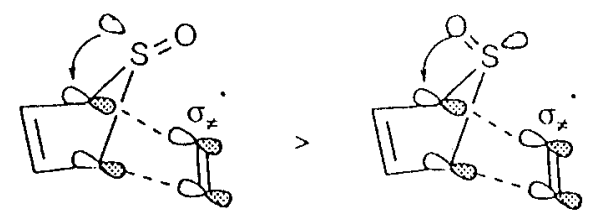

Figure 5.
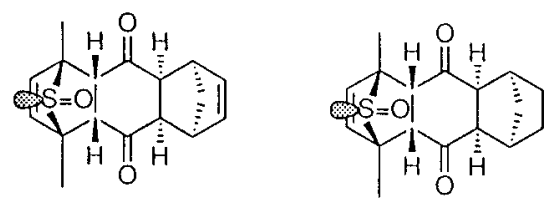

anti- endo

$18 a$

$18 b$

Figure 6.

product, where the double bond of the norbornene unit is hydrogenated exclusively, and not the olefinic bond of the thiabicyclo[2.2.1]heptene oxide moiety (Figure 6).

Although many stereoisomers are possible in the cycloaddition of 2,5-dimethyl- and 2,3,4,5-tetramethylthiophene S-oxide with dienophiles $\mathbf{2 3}$ and $\mathbf{2 5}$, the crude 3062.

(26) Cookson, R. C.; Hill, R. R.; Hudec, J . J . Soc. Chem. 1964, 3043-
Table 2. $\mathrm{BF}_{3} \cdot \mathrm{Et}_{2} \mathrm{O}$-Catalyzed Cycloaddition of Alkylthiophenes with Unreactive Dienophiles (see Scheme 2)

\begin{tabular}{cccccc}
\hline & & & \multicolumn{3}{c}{ products, yield (\%) } \\
\cline { 4 - 6 } entry & thiophenes & dienophiles & $\mathbf{3 0}$ & $\mathbf{3 1}$ & $\mathbf{3 2}$ \\
\hline 1 & $\mathbf{1 a}: \mathrm{R}^{1}=\mathrm{Me}, \mathrm{R}^{2}=\mathrm{H}$ & $\mathrm{n}=1 \mathbf{2 9 a}$ & $\mathbf{3 0 a}(36)$ & & \\
2 & $\mathbf{1 b}: \mathrm{R}^{1}=\mathrm{R}^{2}=\mathrm{Me}$ & $\mathrm{n}=1$ & $\mathbf{3 0 b}(28)$ & $\mathbf{3 1 b}(40)$ & \\
3 & $\mathbf{l a}$ & $\mathrm{n}=2 \mathbf{2 9 b}$ & $\mathbf{3 0 c}(8)$ & & $(50)^{\mathrm{a}}$ \\
4 & $\mathbf{1 b}$ & $\mathrm{n}=2$ & $\mathbf{3 0 d}(25)$ & $\mathbf{3 1 b}(42)$ & \\
5 & $\mathbf{l a}$ & $\mathrm{n}=3 \mathbf{2 9 c}$ & & & $(45)^{\mathrm{a}}$ \\
6 & $\mathbf{1 b}$ & $\mathrm{n}=3$ & $\mathbf{3 0 e}(25)$ & $(54)$ &
\end{tabular}

a Three isomers have been isolated.

Scheme 2
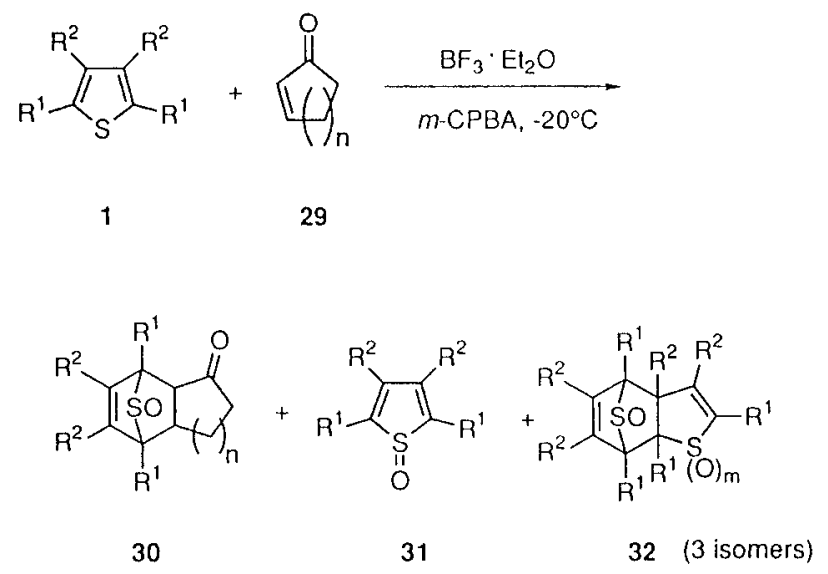

NMR-spectra of cycloadducts 24, 26, 27, and $\mathbf{2 8}$ all show only one cycloadduct formed in each reaction. The cycloaddition of the thiophenes with $\mathbf{2 3}$ and $\mathbf{2 5}$ occurs on the less substituted olefinic bond of the dienophiles. This is in contrast to the furan-analogues, which at low temperatures add to these dienophiles on the more substituted side. 2,5-Dimethylthiophene S-monoxide (31a) is much more reactive than 2,5-dimethylfuran which reacts with $\mathbf{2 3}$ only at temperatures of and above $100{ }^{\circ} \mathrm{C}$. It has been reported that the bisadduct formed with 2,5-dimethylfuran shows the exo-endo configuration, which is kinetically favored over other configurations. ${ }^{27}$ The X-ray analysis of the bis-adduct $\mathbf{2 4}$ showed it to be the exo-endo isomer as well. The same exo-endo configuration can be assumed for $\mathbf{2 6}$ and $\mathbf{2 8}$ from NMR spectra. Here the coupling constant between $\mathrm{H}_{\mathrm{a}}$ and $\mathrm{H}_{\mathrm{b}} \mathrm{J}_{\mathrm{ab}}=0$ $\mathrm{Hz}$, suggesting a dihedral angle between $\mathrm{H}_{\mathrm{a}}$ and $\mathrm{H}_{\mathrm{b}}$ of about $90^{\circ}$ (Figure 3).

Upon addition of $\mathrm{BF}_{3} \cdot \mathrm{Et}_{2} \mathrm{O}$ as Lewis acid catalyst, alkylthiophenes react with mono-activated dienophiles 29a-c under oxidative conditions at $-20^{\circ} \mathrm{C}$, whereas the reaction does not proceed uncatalyzed. In the uncatalyzed reaction only thiophene S,S-dioxides are formed as products. The results of the oxidative cycloaddition of 2,5-dimethylthiophene (1a) and 2,3,4,5-tetramethylthiophene (1b) with less-reactive dienophiles $\mathbf{2 9}$ are summarized in Table 2 (Scheme 2). Here, clearly the success of the cycloaddition of alkylthiophenes with $\mathbf{2 9}$ can be attributed on the one hand to the reactivity enhancement of the dienophiles by the Lewis acid. On the other hand the intermediate thiophene S-monoxides are stabilized against further oxidation to thiophene S,Sdioxides by complexation of $\mathrm{BF}_{3}$ on the oxygen of the

(27) (a) Slee, J . D.; LeGoff, E. J . Org. Chem. 1970, 35, 3897-3901. (b) McCulloch, A. W.; Smith, D. G.; Mclnnes, A. G. Can. J . Chem. 1973, 51, 4125-4136. 


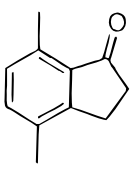

34

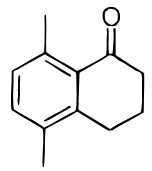

35

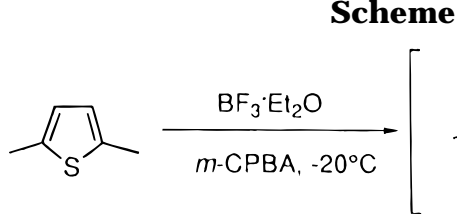

$1 a$

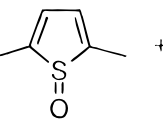

$31 \mathrm{a}$

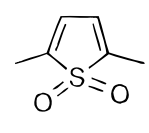

33

\section{Figure 7.}

sulfoxy-moiety, as mentioned above. 2,5-Dimethylthiophene in its reaction with cyclopent-2-enone (29a) gave cycloadduct 30 a as the only isolated product in $36 \%$ yield. In the cycloaddition of 2,5-dimethylthiophene with cyd ohex-2-enone (29b) only $8 \%$ of the cycloadduct $\mathbf{3 0 c}$ could be isolated along with dimers (32) of the intermediary produced thiophene S-monoxide with the thiophene S,Sdioxide in $50 \%$ yield. The ene-system in cyclohept-2enone (29c) is less strained than in $\mathbf{2 9 a}$ or $\mathbf{2 9} \mathbf{b}$; thus the reactivity of $\mathbf{2 9 c}$ as dienophile is lower. No cycl oadduct of 2,5-dimethylthiophene S-oxide (31a) with $\mathbf{2 9 c}$ could be isolated. 2,5-Dimethylthiophene S-oxide dimerized under the conditions and gave only $\mathbf{3 2}$ as products. Clearly the dimerization of the thiophene S-monoxides becomes a competing factor at this point (see also below). Nevertheless, there are thiophene S-monoxides which do not dimerize readily. Thus the reaction of tetramethylthiophene with dienophiles $\mathbf{2 9 a}-\mathbf{c}$ gave the corresponding cycloadducts $\mathbf{3 0 b}, \mathbf{3 0 d}$, and $30 \mathbf{e}$ and the tetramethylthiophene S-monoxide (31b). It is interesting to note that $\mathbf{3 1 b}$ is a stable product, although thus far only thiophene S-monoxides had been isolated with bulky substituents at positions 2 and 5. Cycloadducts $30 \mathrm{a}$ and 30c are unstable even at low temperature and extrude their SO-bridge readily to give the indanone $\mathbf{3 4}$ and tetralone $\mathbf{3 5}$ (Figure 7).

It is known that the oxidation of thiophene and substituted thiophenes leads to cycloadducts of the intermediate thiophene S-monoxides as byproducts (see also above). They have been named "sesquioxides". ${ }^{28}$ The oxidation of bulkier substituted thi ophenes yields virtually no sesquioxides due to steric hindrance. Usually only thiophene S,S-dioxides are produced in these cases. Only a few sesquioxides have been isolated to date and mostly in low yields; the stereochemistry of these compounds has been conjectured from IR and NMR spectra. ${ }^{29}$

In order to obtain more information about the dimerization of thiophene S-oxides, especially in view of the competition of this reaction with the cycloaddition of thiophene S-oxides with other dienophiles, the authors attempted a selective preparation of sesquioxides under Lewis acid catalysis. 2,5-Dimethylthiophene (1a) was oxidized with $\mathrm{m}-\mathrm{CPBA}$ in the presence of $\mathrm{BF}_{3} \cdot \mathrm{Et}_{2} \mathrm{O}$ (Scheme 3). After no more 2,5-dimethylthiophene could be identified in the reaction mixture, $\mathrm{BF}_{3} \cdot \mathrm{Et}_{2} \mathrm{O}$, excess $m-C P B A$ and $m$-chlorobenzoic acid were extracted from the reaction mixture. The resulting product solution in dichloromethane showed 2,5-dimethylthiophene S-oxide on TLC. It dimerized, however, as soon as the solvent was evaporated in vacuo, and three dimers could be

(28) (a) Prochazka, M. Coll. Czech Chem. Commun. 1965, 30, 1158. (b) Davies, W.; Gamble, N.; J ames, F. C.; Savige, W. Chem. Ind. (London) 1952, 804-804. (c) Melles, J .; Backer, H.j. Red. Trav. Chim. Pays-Bas 1953, 72, 491-496. (d) Davies, W.; J ames, F. C. J . Chem Soc. 1954, 15-18. (e) Okita, K.; Kambara, S. Kogyo Kagaku Zasshi 1956, 59, 547-549. Chem. Abstr. 1958, 52, 3762.

(29) Merrill, R. E.; Sherwood, G. J . Heterocycl. Chem. 1977, 14, 1251-1253.

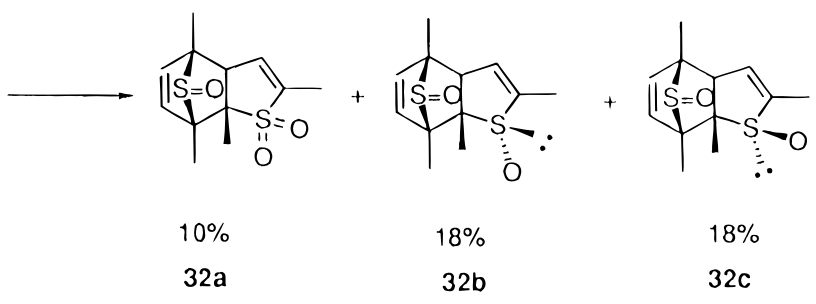

Scheme 4
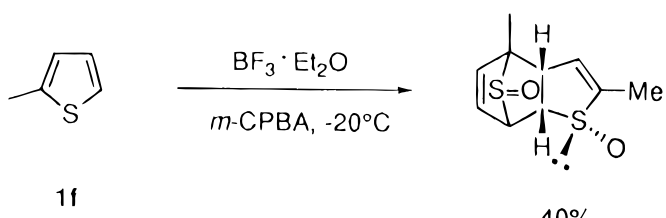

$40 \%$

36

isolated by careful column chromatography. ${ }^{1} \mathrm{H},{ }^{13} \mathrm{C}$ NMR, and mass spectra and elemental analysis showed 32a to be a Diels-Alder adduct formed by 2,5-dimethylthiophene S-oxide acting as diene and 2,5-dimethylthiophene S,S-dioxide acting as dienophile. The infrared spectrum of $\mathbf{3 2 a}$ confirmed the presence of a sulfoxide$\left(1079 \mathrm{~cm}^{-1}\right)$ and a sulfone-group $\left(1146 \mathrm{~cm}^{-1}, 1284 \mathrm{~cm}^{-1}\right)$, while the IR spectra of $\mathbf{3 2} \mathbf{b}$ and $\mathbf{3 2}$ c only showed SO stretching frequency in the range of $1000-1100 \mathrm{~cm}^{-1}$. 32b and 32c are dimerized cycloadducts of 2,5-dimethylthiophene S-oxide acting as both diene and dienophile. The difference between $\mathbf{3 2 b}$ and $\mathbf{3 2 c}$ is the stereochemistry at one of the sulfur atoms. Meanwhile all three structures have been confirmed by X-ray structure analysis. ${ }^{30}$ The three cycloadducts have endo-configuration, and the bridged sulfoxy-moiety is configurated in such a way that the lone electron pair is directed toward the newly formed double bond, in accordance to the Cieplak-effect. ${ }^{24}$ It is also interesting to note that in the formation of 32a thiophene S,S-dioxide plays indeed the role of the dienophile, as under the reaction conditions described, no further oxidation at sulfur can take place after the cycloaddition.

Under the same conditions at $-20^{\circ} \mathrm{C}$, 2-methylthiophene (1f) gives a single dimer 36 of 2-methylthiophene S-oxide, stereoselectively and in $40 \%$ yield (Scheme 4 ). It has been known that a single sesquioxide is isolated in the uncatalyzed reaction, when $\mathbf{1 f}$ is oxidized by $\mathrm{m}-\mathrm{CPBA}$ at $0-10^{\circ} \mathrm{C}$. The structure of $\mathbf{3 6}$ we first have assigned on the basis of its ${ }^{1} \mathrm{H} N M R,{ }^{13} \mathrm{C} \mathrm{NMR},{ }^{1} \mathrm{H}-{ }^{1} \mathrm{H}$ COSY, and ${ }^{13} \mathrm{C}-{ }^{1} \mathrm{H}$ COSY spectra; it shows coupling patterns in the ${ }^{1} \mathrm{H}$ NMR similar to those described by W. J. M. van Tilborg ${ }^{31}$ for 34 . The stereochemistry at the sulfur atoms was determined by an X-ray analysis ${ }^{31}$ of 36 (Figure 8); it shows the two SO groups to be anticonfigured as in cycloadduct $\mathbf{3 2} \mathbf{b}$.

Tetraalkyl substituted thiopheneS-monoxides $\mathbf{3 1 b}$ and 31c could be isolated as stable compounds in 75\% yield

(30) Li, Y.-Q.; Sawada, T.; Thiemann, T.; Hanss, J .; Mataka, S.; Tashiro, M. Acta Crystallogr., submitted.

(31) Van Tilborg, W. J . M. Synth. Commun. 1976, 6, 583-589. 


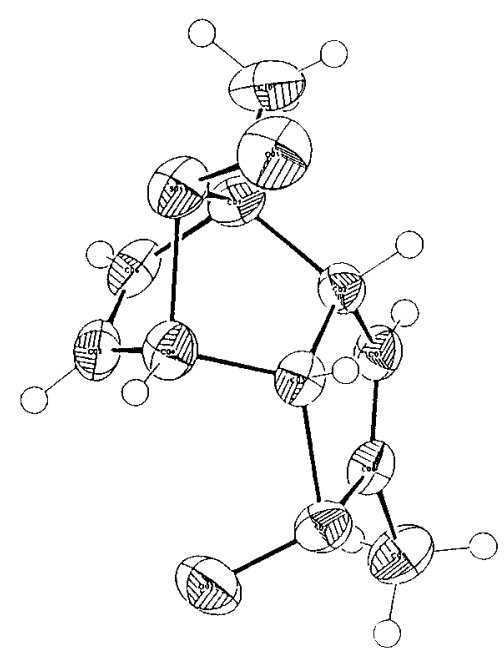

Figure 8. ORTEP structure of 36.

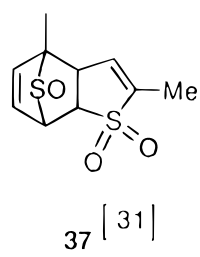

Figure 9.

Scheme 5

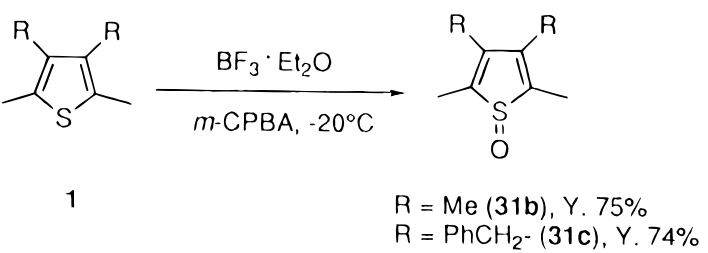

(Scheme 5). They showed no tendency to dimerize immediately after workup. A formation of thiopheneS,Sdioxides as byproducts could be prevented by using a 4-fold amount of $\mathrm{BF}_{3} \cdot \mathrm{Et}_{2} \mathrm{O}$ during the oxidation. Compound 31c is rather stable in the solid state and does not change for a long time when at room temperature. 31b, however, dimerizes sl owly to give three isomers after a couple of days at room temperature. Unfortunately 31c is more sensitive in solution, and it was difficult to get proper crystals of 31c for X-ray analysis.

The oxidation of the two-core compound $\mathbf{3 8}$ gives the mono thiophene S-monoxide (39) and the bis-thiophene S-monoxide (40) (Scheme 6). The yields of 39 and $\mathbf{4 0}$ depend on the number of equivalents of m-CPBA used in the reaction. Interestingly the thiophene ring in $\mathbf{3 9}$ can compete with the thiophene S-monoxide unit for the $\mathrm{m}-\mathrm{CPBA}$. This clearly shows that the use of $\mathrm{BF}_{3}$ shields the thiophene S-monoxide from further oxidation to thiophene S,S-dioxide. Compound $\mathbf{4 0}$ reacts with dimethyl acetylenedicarboxylate at room temperature to give the bisarene $\mathbf{4 1}$ in $60 \%$ yield (Scheme 7). As is usual in reactions with alkynes, the primary cycloadduct is unstable and extrudes SO immediately to give the aromatized products.

\section{Conclusion}

Alkylthiophenes and some halogen-substituted thiophenes cycloadd with dienophiles, when they are oxidized
Scheme 6

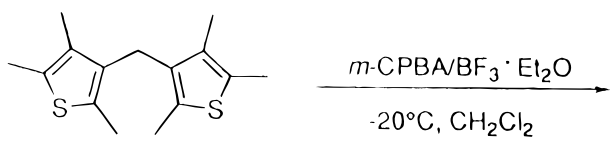

38

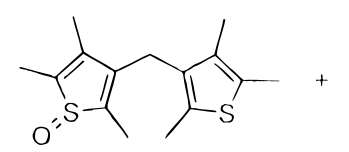

39

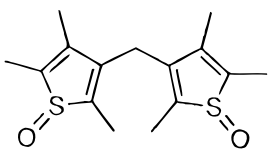

40

\begin{tabular}{lll} 
& \multicolumn{2}{c}{ yield $(\%)$} \\
\cline { 2 - 3 } m-CPBA & 39 & 40 \\
\hline $\begin{array}{l}1.5 \text { equiv. } \\
3.0 \text { equiv. }\end{array}$ & 50 & 30 \\
\end{tabular}

Scheme 7
40

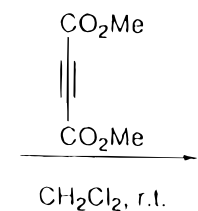

$\mathrm{CH}_{2} \mathrm{Cl}_{2}, \mathrm{r} . \mathrm{l}$.
41<smiles>COC(=O)c1c(C)c(C)c(Cc2c(C)c(C(=O)OC)c(C)c(C(OC)OC)c2C)c(C)c1C</smiles>

in situ by $\mathrm{m}$-CPBA. These reactions can be catalyzed by $\mathrm{BF}_{3} \cdot \mathrm{Et}_{2} \mathrm{O}$ as Lewis acid with enhanced yields of up to $75 \%$. The Lewis acid is thought to complex to the oxygen of the sulfoxy-moiety and to have two effects: (1) It decreases the nucleophilicity of the sulfur of the sulfoxymoiety and thus decreases its oxidativity. (2) It increases the stereoselectivity in certain cycloadditions. Moreover, the Lewis acid catalyst increases the reactivity of certain dienophiles and thus enlarges the variety of possible dienophiles for the oxidative cycloaddition of thiophenes.

This reaction can be performed in two ways, in a onepot reaction or a two-step synthesis. In the two-step sequence it is possible to prepare alkyl-substituted thiophene S-monoxides in solution by oxidation of thiophenes with $\mathrm{m}$-CPBA under $\mathrm{BF}_{3} \cdot \mathrm{Et}_{2} \mathrm{O}$ catalysis; they can be reacted with dienophiles under neutral conditions in a second step. This prevents the decomposition of acidlabile dienophiles. The oxidative cycloaddition of thiophenes under $\mathrm{BF}_{3}$ catalysis always gives endo-products with the bridge $\mathrm{S}=\mathrm{O}$ group always directed to the approaching dienophile.

Oxidation of 2-methylthiophene and 2,5-dimethylthiophene under $\mathrm{BF}_{3}$-catalysis gives dimers of the corresponding thiopheneS-monoxides, which act as both the diene and the dienophile. When 2,3,4,5-tetramethylthiophene and 3,4-dibenzyl-2,5-dimethylthiophene are oxidized with $\mathrm{m}$-CPBA in the presence of $\mathrm{BF}_{3}$, the corresponding thiophene S-monoxides have been isolated as stable products.

\section{Experimental Section}

Melting points were determined on a Mitamurariken MELT THERMO and are uncorrected. IR spectra were recorded on a J ASCO-102 spectrometer. NMR spectra were recorded at $270 \mathrm{MHz}$ (proton) and at $67.9 \mathrm{MHz}$ (carbon-13) with a J EOL 
GSX-270 spectrometer with $\mathrm{SiMe}_{4}$ as internal standard. J values are given in $\mathrm{Hz}$. UV spectra were measured on a Hitachi 220A spectrophotometer. Mass spectra were obtained on a J EOL J MS-O1SG-2 mass spectrometer at $70 \mathrm{eV}$ using a direct-inlet system. Column chromatography was carried out on silica gel (Wako gel, C-300).

N-Phenyl-1,4-dimethyl-7-thiabicyclo[2.2.1]hept-5-ene2,3-dicarboxamide 7-oxide (3). A Typical One-Pot Procedure for the $\mathrm{BF}_{3} \cdot \mathrm{Et}_{2} \mathrm{O}-\mathrm{C}$ atalyzed Oxidative Cycloaddition of Thiophenes with Dienophiles. To a solution of 2,5-dimethylthiophene (300 mg, $2.68 \mathrm{mmol}$ ) and $\mathrm{N}$-phenylmaleimide $(700 \mathrm{mg}, 4.05 \mathrm{mmol})$ in dry $\mathrm{CH}_{2} \mathrm{Cl}_{2}(10 \mathrm{~mL})$ was added slowly $\mathrm{BF}_{3} \cdot \mathrm{Et}_{2} \mathrm{O}(2 \mathrm{~mL}, 16.2 \mathrm{mmol})$ under an inert atmosphere and at $-20^{\circ} \mathrm{C}$. The reaction mixture was stirred for $10 \mathrm{~min}$ at $-20^{\circ} \mathrm{C}$, and then a solution of $\mathrm{m}$-CPBA (700 $\mathrm{mg}, 4.06 \mathrm{mmol}$ ) in dry $\mathrm{CH}_{2} \mathrm{Cl}_{2}(15 \mathrm{~mL}$ ) was added slowly. The reaction mixture was stirred for $2 \mathrm{~h}$ at $-20^{\circ} \mathrm{C}$. Then the suspension was poured into a mixture of concd aqueous $\mathrm{NaHCO}_{3}$ solution $(30 \mathrm{~mL})$ and $\mathrm{CH}_{2} \mathrm{Cl}_{2}(50 \mathrm{~mL})$ and stirred at room temperature for $20 \mathrm{~min}$. The organic phase was separated, and the aqueous phase was extracted with $\mathrm{CH}_{2} \mathrm{Cl}_{2}(3 \times 20 \mathrm{~mL})$. The combined organic phase was washed with water and brine and dried over anhydrous $\mathrm{MgSO}_{4}$. After removal of the solvent in vacuo, the residue was chromatographed on silica gel to give 3 as colorless crystals (630 mg, 78\%). 3: $\mathrm{mp} 174-175^{\circ} \mathrm{C}$ (from ether); ${ }^{1} \mathrm{H}$ NMR $\left(270 \mathrm{MHz}_{2} \mathrm{CDCl}_{3}\right) \delta\left(\mathrm{s}, 6 \mathrm{H}, 2 \mathrm{CH}_{3}\right), 3.83(\mathrm{~s}, 2 \mathrm{H}), 6.21$ (s, $2 \mathrm{H}), 7.15(\mathrm{~m}, 2 \mathrm{H}), 7.35-7.53(\mathrm{~m}, 3 \mathrm{H}) ;{ }^{13} \mathrm{C} \mathrm{NMR}(67.9 \mathrm{MHz}$; $\left.\mathrm{CDCl}_{3}\right) \delta 14.27,50.40,72.56,126.50,128.93,131.53,132.56$, 174.18; IR (KBr) $1774(C=0), 1711(C=0), 1081,1063 \mathrm{~cm}^{-1}$; MS (70 eV) m/z (\%) $301\left(\mathrm{M}^{+}, 0.7\right), 253\left(\mathrm{M}^{+}-\mathrm{SO}, 85.6\right)$. Anal. Calcd for $\mathrm{C}_{16} \mathrm{H}_{15} \mathrm{NO}_{3} \mathrm{~S}$ : C, 63.77; $\mathrm{H}, 4.64 ; \mathrm{N}, 5.01$. Found: $\mathrm{C}$, 63.77; H, 4.49; N, 5.00.

N-Phenyl-2,3,4,5-tetramethyl-7-thiabicyclo[2.2.1]hept5-ene-2,3-dicarboximide 7-Oxide (4). 1 b (300 mg, 2.14 $\mathrm{mmol})$ was reacted with $\mathrm{BF}_{3} \cdot \mathrm{Et}_{2} \mathrm{O}(3 \mathrm{~mL}, 24.3 \mathrm{mmol}), \mathrm{m}-\mathrm{CPBA}$ (480 $\mathrm{mg}, 2.78 \mathrm{mmol}$ ), and $\mathrm{N}$-phenylmaleimide (130 $\mathrm{mg}, 0.7$ $\mathrm{mmol})$ as described for 3 to give $\mathbf{4}(420 \mathrm{mg}, 74 \%)$ : $\mathrm{mp} 225-$ $226{ }^{\circ} \mathrm{C}$ (from ether); ${ }^{1} \mathrm{H}$ NMR $\left(270 \mathrm{MHz} \mathrm{CDCl}_{3}\right) \delta 1.75(\mathrm{~s}, 6 \mathrm{H}$, $\left.2 \mathrm{CH}_{3}\right), 1.80\left(\mathrm{~s}, 6 \mathrm{H}, 2 \mathrm{CH}_{3}\right), 3.75(\mathrm{~s}, 2 \mathrm{H}), 7.10(\mathrm{~m}, 2 \mathrm{H}), 7.35-$ $7.55(\mathrm{~m}, 3 \mathrm{H}) ;{ }^{13} \mathrm{C} \mathrm{NMR}\left(67.9 \mathrm{MHz}, \mathrm{CDCl}_{3}\right) \delta 11.88,12.97,50.95$, 73.22, 126.36, 128.89, 129.31, 131.61, 131.75, 174.50; IR (KBr) 3074, $1773(C=0), 1714(C=0), 1596,1495,1452,1370,1178$, 1102, $1066 \mathrm{~cm}^{-1}$; MS (70 eV) m/z (\%) $329\left(\mathrm{M}^{+}, 4.6\right), 281\left(\mathrm{M}^{+}-\right.$ SO, 17.6). Anal. Calcd for $\mathrm{C}_{18} \mathrm{H}_{19} \mathrm{NO}_{3} \mathrm{~S}: \mathrm{C}, 65.57 ; \mathrm{H}, 5.90 ; \mathrm{N}$, 4.19. Found: C, 65.65; $H, 5.78 ; \mathrm{N}, 4.26$.

N-Phenyl-3,4-dibenzyl-2,6-dimethyl-7-thiabicyclo[2.2.1]hept-5-ene-3,3-carbox-imide 7-Oxide (5). 1c (300 mg, 1.03 $\mathrm{mmol}$ ) was treated with $\mathrm{BF}_{3} \cdot \mathrm{Et}_{2} \mathrm{O}(2 \mathrm{~mL}, 16.1 \mathrm{mmol}), \mathrm{m}-\mathrm{CPBA}$ (250 mg, $1.45 \mathrm{mmol}$ ), and $\mathrm{N}$-phenylmaleimide (250 mg, 1.45 $\mathrm{mmol})$ as described for $\mathbf{3}$ to give $\mathbf{5}$ (350 $\mathrm{mg}, 70 \%)$ : $\mathrm{mp} 72-73$

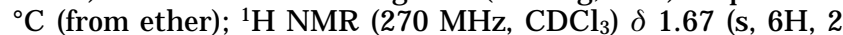
$\left.\mathrm{CH}_{3}\right), 3.56\left(\mathrm{~d}, 2 \mathrm{H},{ }^{2} \mathrm{~J}=16.0 \mathrm{~Hz}\right), 3.76(\mathrm{~s}, 2 \mathrm{H}), 3.82\left(\mathrm{~d}, 2 \mathrm{H},{ }^{2} \mathrm{~J}\right.$ $=16.0 \mathrm{~Hz}), 7.04-7.52(\mathrm{~m}, 15 \mathrm{H}) ;{ }^{13} \mathrm{C} \mathrm{NMR}\left(67.9 \mathrm{MHz} \mathrm{CDCl}_{3}\right)$ $\delta$ 13.46, 32.72, 51.23, 73.94, 126.13, 126.77, 128.43, 128.68, $128.73,128.95,129.14,131.62,136.94,137.05,147.09 ;$ IR $(\mathrm{KBr})$ $1700(\mathrm{C}=\mathrm{O})$ and $1060 \mathrm{~cm}^{-1}$; MS (70 eV) m/z (\%) $433\left(\mathrm{M}^{+}-\right.$ SO, 47.1), 342 (6.9), 193 (100). HRMS m/ $/ \mathrm{CC}_{30} \mathrm{H}_{27} \mathrm{NO}_{3} \mathrm{~S}$ : Calcd 481.1712, Found: 481.1818. Anal. Calcd for $\mathrm{C}_{30} \mathrm{H}_{27} \mathrm{NO}_{3} \mathrm{~S}$ : C, 74.82; H, 5.65; N, 2.91. Found C, 74.82; H, 5.84; N, 2.83.

N-Phenyl-2,3-dibromo-1,4-dimethyl-7-thiabicyclo[2.2.1]hept-5-ene-2,3-dicarboximide 7-0xide (7). le (300 mg, $1.11 \mathrm{mmol})$ was transformed with $\mathrm{BF}_{3} \cdot \mathrm{Et}_{2} \mathrm{O}(2 \mathrm{~mL}, 16.2 \mathrm{mmol})$, m-CPBA (480 mg, $2.78 \mathrm{mmol}$ ), and $\mathrm{N}$-phenylmaleimide (250 $\mathrm{mg}, 1.45 \mathrm{mmol}$ ) to produce 7 (280 $\mathrm{mg}, 55 \%): \mathrm{mp} 232-234{ }^{\circ} \mathrm{C}$ (from hexane/benzene); ${ }^{1 \mathrm{H}} \mathrm{NMR}\left(270 \mathrm{MHz} \mathrm{CDCl}_{3}\right) \delta 1.90$ (s, $\left.6 \mathrm{H}, 2 \mathrm{CH}_{3}\right), 3.88(\mathrm{~s}, 2 \mathrm{H}), 7.16(\mathrm{~m}, 2 \mathrm{H}), 7.43-7.48(\mathrm{~m}, 3 \mathrm{H})$; IR $(\mathrm{KBr}) 1781(\mathrm{C}=\mathrm{O}), 1715(\mathrm{C}=\mathrm{O}), 1037(\mathrm{w}), 991(\mathrm{~s}, \mathrm{~S}=\mathrm{O}) \mathrm{cm}^{-1}$; MS (70 eV) m/z (\%) 413, 411, $409\left(M^{+}-\right.$SO, 15.8). HRMS $\mathrm{m} / \mathrm{Z} \mathrm{C}_{16} \mathrm{H}_{13} \mathrm{Br}_{2} \mathrm{NO}_{3} \mathrm{~S}$ : Calcd 4060.8944; 458.8963; 456.8983. Found: 460.8949; 458.8960; 456.8980. Anal. Calcd for $\mathrm{C}_{16} \mathrm{H}_{13} \mathrm{Br}_{2} \mathrm{NO}_{3} \mathrm{~S}$ : C, 41.85; $\mathrm{H}, 2.85 ; \mathrm{N}, 3.05$. Found: C, 41.24; $\mathrm{H}, 3.10 ; \mathrm{N}, 3.82$.

1,12-Dimethyl-15-thiatetracyclo[10.2.1.02,11.04,9]pentadeca-4,6,8,13-tetraene-3,10-dione 15-Oxide (16). Cycloaddition of 2,5-Dimethylthiophene to Naphthoquinone (15). 1 a ( $250 \mathrm{mg}, 2.23 \mathrm{mmol}$ ) was reacted with $\mathrm{BF}_{3} \cdot \mathrm{Et}_{2} \mathrm{O}$
(3 $\mathrm{mL}, 24.3 \mathrm{mmol}), \mathrm{m}$-CPBA (580 $\mathrm{mg}, 3.36 \mathrm{mmol})$, and naphthoquinone ( $800 \mathrm{mg}, 4.6 \mathrm{mmol})$ as described for 3 to give 16 (440 mg, 52\%): $\mathrm{mp} 169-170{ }^{\circ} \mathrm{C}$ dec; ${ }^{1} \mathrm{H}$ NMR $(270 \mathrm{MHz}$, $\left.\mathrm{CDCl}_{3}\right) \delta 1.75\left(\mathrm{~s}, 6 \mathrm{H}, 2 \mathrm{CH}_{3}\right), 3.83(\mathrm{~s}, 2 \mathrm{H}), 5.88(\mathrm{~s}, 2 \mathrm{H}), 7.73$ $(\mathrm{dd}, 2 \mathrm{H}$, J $=3.3 \mathrm{~Hz}$, J $=5.9 \mathrm{~Hz}$ ), 7.99 (dd, $2 \mathrm{H}$, J $=3.3 \mathrm{~Hz}$, J $=5.9 \mathrm{~Hz}) ;{ }^{13} \mathrm{C} \mathrm{NMR}\left(67.9 \mathrm{MHz} \mathrm{CDCl}_{3}\right) \delta 14.34,52.74,74.25$, $126.70,132.76,134.46,136.69,194.93$; IR (KBr) $1679(\mathrm{C}=0)$ and $1076 \mathrm{~cm}^{-1}$; MS (70 eV) m/z (\%) $238\left(\mathrm{M}^{+}-\mathrm{SO}, 28\right), 223$ (4.2). HRMS m/z C ${ }_{16} \mathrm{H}_{14} \mathrm{O}_{3} \mathrm{~S}$ : Calcd 286.0664. Found 286.0656. Anal. Calcd for $\mathrm{C}_{16} \mathrm{H}_{14} \mathrm{O}_{3} \mathrm{~S}$ : C, 67.12; $\mathrm{H}, 4.92$. Found: C, $67.04 ; \mathrm{H}, 5.43$.

1,12-Dimethyl-15-thiapentacyclo[10.2.1.1 $\left.1,8.0^{2,4} \cdot 0^{4,9}\right]-$ hexadeca-6,13-diene-3,10-dione 15-Oxide (18a). 18a: (440 mg, 65\%): mp $282-283{ }^{\circ} \mathrm{C}$ (dec, from benzene); ${ }^{1} \mathrm{H}$ NMR (270 $\left.\mathrm{MHz} \mathrm{CDCl}_{3}\right) \delta 1.23(\mathrm{~d}, 1 \mathrm{H}, \mathrm{j}=9.0 \mathrm{~Hz}), 1.47(\mathrm{~d}, 1 \mathrm{H}, 2 \mathrm{~J}=9.0$ $\mathrm{Hz}), 1.54\left(\mathrm{~s}, 6 \mathrm{H}, 2 \mathrm{CH}_{3}\right), 2.96(\mathrm{~m}, 2 \mathrm{H}), 3.26(\mathrm{~s}, 2 \mathrm{H}), 3.36(\mathrm{~m}$, $2 \mathrm{H}), 6.18(\mathrm{~m}, 2 \mathrm{H}), 6.24(\mathrm{~s}, 2 \mathrm{H}) ;{ }^{13} \mathrm{C} \mathrm{NMR}\left(67.9 \mathrm{MHz}^{\left.-\mathrm{CDCl}_{3}\right) \delta}\right.$ $13.69,45.71,47.53,57.34,73.76,132.90,137.10,208.44$; IR $(\mathrm{KBr}) 1700(\mathrm{C}=\mathrm{O}), 1070,1050,1030 \mathrm{~cm}^{-1}$; MS (70 eV) m/z (\%) $302\left(\mathrm{M}^{+}, 32.5\right), 226\left(\mathrm{M}^{+}-\mathrm{SO}, 10\right), 210$ (8.7). Anal. Calcd for $\mathrm{C}_{17} \mathrm{H}_{18} \mathrm{O}_{3} \mathrm{~S}: \mathrm{C}, 67.52 ; \mathrm{H}, 6.00$. Found: $\mathrm{C}, 67.54 ; \mathrm{H}, 6.03$.

1,12-Dimethyl-15-thiapentacyclo[10.2.1.1 $\left.1,8 \cdot 0^{2,4}, 0^{4,9}\right]-$ hexadeca-13-ene-3,10-dione 15-Oxide (18b). A mixture of $18 \mathbf{a}(120 \mathrm{mg}, 0.40 \mathrm{mmol})$ and $\mathrm{Pd} / \mathrm{C}(10 \mathrm{wt} \%, 10 \mathrm{mg})$ in $\mathrm{MeOH}$ $(5 \mathrm{~mL})$ was stirred under a hydrogen atmosphere. After $24 \mathrm{~h}$ $\mathrm{Pd} / \mathrm{C}$ was filtered off and washed with $\mathrm{MeOH}$. The filtrate was concentrated in vacuo to yield $\mathbf{1 8 b}$ (100 $\mathrm{mg}, 83 \%$ ) as colorless crystals.

18b: (100 mg, 83\%): $\mathrm{mp} 185^{\circ} \mathrm{C}$ (dec, from ether); ${ }^{1} \mathrm{H}$ NMR $\left(270 \mathrm{MHz} \mathrm{CDCl}_{3}\right) \delta 1.13-1.38(\mathrm{~m}, 6 \mathrm{H}), 1.47(\mathrm{~s}, 6 \mathrm{H}), 2.54(\mathrm{~s}$, $2 \mathrm{H}), 2.65(\mathrm{~s}, 2 \mathrm{H}), 3.31(\mathrm{~s}, 2 \mathrm{H}), 6.16(\mathrm{~s}, 2 \mathrm{H}) ;{ }^{13} \mathrm{C} \mathrm{NMR}(67.9$ $\left.\mathrm{MHz}_{2} \mathrm{CDCl}_{3}\right) \delta 12.45,22.71,38.69,52.72,56.86,73.24,131.55$, 207.31; IR (KBr) $1690(\mathrm{C}=\mathrm{O}), 1440,1070 \mathrm{~cm}^{-1}$; MS (70 eV) $\mathrm{m} / \mathrm{z}(\%) 256\left(\mathrm{M}^{+}-\mathrm{SO}\right)$, 241. HRMS m/z $\mathrm{C}_{17} \mathrm{H}_{20} \mathrm{O}_{3} \mathrm{~S}$ : Calcd 304.1133. Found: 304.1125.

1,8-Dimethyl-11-thiatricyclo[6.2.1.02,7]undeca-4,9-diene3,6-dione 11-Oxide (20). Cycloaddition of 2,5-Dimethylthiophene with p-Benzoquinone (19). 1a (300 mg, 2.68 $\mathrm{mmol}$ ) was treated with $\mathrm{BF}_{3} \cdot \mathrm{Et}_{2} \mathrm{O}(2 \mathrm{~mL}, 16.2 \mathrm{mmol}), \mathrm{m}-\mathrm{CPBA}$ (600 mg, $3.48 \mathrm{mmol}$ ), and p-benzoquinone (580 mg, $5.3 \mathrm{mmol}$ ) as described for 3 to yield 20 (370 mg, 58\%): $\mathrm{mp} 152-154{ }^{\circ} \mathrm{C}$ (dec, from benzene, lit. $\left.139{ }^{\circ} \mathrm{C}^{11}\right) ;{ }^{1} \mathrm{H}$ NMR $\left(270 \mathrm{MHz}, \mathrm{CDCl}_{3}\right)$ $\delta 1.63\left(\mathrm{~s}, 6 \mathrm{H}, 2 \mathrm{CH}_{3}\right), 3.54(\mathrm{~s}, 2 \mathrm{H}), 5.99(\mathrm{~s}, 2 \mathrm{H}), 6.62(\mathrm{~s}, 2 \mathrm{H})$; ${ }^{13} \mathrm{C} \mathrm{NMR}\left(67.9 \mathrm{MHz} \mathrm{CDCl}_{3}\right) \delta 14.21,51.45,73.84,132.88$, 143.01, 196.37; MS (70 eV) m/z (\%) $236\left(\mathrm{M}^{+}, 32.5\right), 188\left(\mathrm{M}^{+}\right.$ SO, 77).

1,8,9,10-Tetramethyl-11-thiatricyclo[6.2.1.02,7]undeca4,9-diene-3,6-dione 11-Oxide (21). Cycloaddition of 2,3,4,5Tetramethylthiophene with p-Benzoquinone (19). 1b (300 mg, $1.03 \mathrm{mmol}$ ) was reacted with $\mathrm{BF}_{3} \cdot \mathrm{Et}_{2} \mathrm{O}(2 \mathrm{~mL}, 16.2$ mmol), m-CPBA (550 mg, $3.2 \mathrm{mmol}$ ), and p-benzoquinone (460 $\mathrm{mg}, 4.29 \mathrm{mmol}$ ) as described for $\mathbf{3}$ to give $\mathbf{2 1}(370 \mathrm{mg}, 60 \%)$ : mp $175^{\circ} \mathrm{C}$ (dec., from ether); ${ }^{1} \mathrm{H} \mathrm{NMR}\left(270 \mathrm{MHz}, \mathrm{CDCl}_{3}\right) \delta$ $1.61\left(\mathrm{~s}, 6 \mathrm{H}, 2 \mathrm{CH}_{3}\right), 1.63\left(\mathrm{~s}, 6 \mathrm{H}, 2 \mathrm{CH}_{3}\right), 3.51(\mathrm{~s}, 2 \mathrm{H}), 6.64(\mathrm{~s}$, $2 \mathrm{H}) ;{ }^{13} \mathrm{C}$ NMR $\left(67.9 \mathrm{MHz}, \mathrm{CDCl}_{3}\right) \delta 11.90,12.79,52.40,74.68$, 132.00, 142.50, 196.69; IR (KBr) 1676, $1072(\mathrm{~s}), 1035 \mathrm{~cm}^{-1}$. MS (70 eV) m/z (\%) $264\left(M^{+}, 4.0\right), 216\left(M^{+}-\right.$SO, 91.2). Anal. Calcd for $\mathrm{C}_{14} \mathrm{H}_{16} \mathrm{O}_{3} \mathrm{~S}$ : C, 63.61; $\mathrm{H}, 6.10$. Found: $\mathrm{C}, 63.56 ; \mathrm{H}$, 6.28 .

$1,5,8,12-T$ etramethyl-15,16-dithiapentacyclo$\left[10.2 .1 .15,8,0^{2,11} .0^{4,9}\right]$ hexadeca-6,13-diene-3,10-dione 15,16Dioxide (22). Synthesis of Bis-Cycloadduct of 2,5Dimethylthiophene with p-Benzoquinone (19). Typical Two-Step Procedure of Oxidative Cycloaddition of Thiophenes with Dienophiles. $\mathrm{BF}_{3} \cdot \mathrm{Et}_{2} \mathrm{O}(2 \mathrm{~mL}, 16.2 \mathrm{mmol})$ was added to a solution of 2,5-dimethylthiophene ( $300 \mathrm{mg}, 2.68$ $\mathrm{mmol})$ in dry $\mathrm{CH}_{2} \mathrm{Cl}_{2}(10 \mathrm{~mL})$ under an inert atmosphere and at $-20{ }^{\circ} \mathrm{C}$. The mixture was stirred for $10 \mathrm{~min}$ at $-20{ }^{\circ} \mathrm{C}$. Then a solution of m-CPBA (700 mg, $4.06 \mathrm{mmol}$ ) in $\mathrm{CH}_{2} \mathrm{Cl}_{2}$ $(20 \mathrm{~mL}$ ) was added dropwise, and the resulting mixture was stirred for $2 \mathrm{~h}$ at $-20^{\circ} \mathrm{C}$. Then the suspension was poured into a mixture of concd aqueous $\mathrm{NaHCO}_{3}$ solution $(20 \mathrm{~mL})$ and $\mathrm{CH}_{2} \mathrm{Cl}_{2}(50 \mathrm{~mL})$ and stirred at room temperature for $20 \mathrm{~min}$. The organic phase was separated, and the aqueous phase was extracted with $\mathrm{CH}_{2} \mathrm{Cl}_{2}(3 \times 20 \mathrm{~mL})$. The combined organic solution was washed with water and dried over anhydrous 
$\mathrm{MgSO}_{4}$. The $\mathrm{MgSO}_{4}$ was filtered off, and to the filtrate was added p-benzoquinone (100 mg, $0.9 \mathrm{mmol}$ ) in several portions until the 2,5-dimethylthiophene S-oxide reached completely (TLC control). The solvent was evaporated in vacuo, and the residue was chromatographed on silica gel to give a trace of 20 (10 mg, 4\%) and 22 (320 mg, 50\%) as colorless crystals.

22: $\mathrm{mp} 204{ }^{\circ} \mathrm{C}$ (from ether); ${ }^{1} \mathrm{H}-\mathrm{NMR}\left(270 \mathrm{M} \mathrm{Hz} \mathrm{CDCl}_{3}\right) \delta$ $1.63\left(\mathrm{~s}, 12 \mathrm{H}, 4 \mathrm{CH}_{3}\right), 3.40(\mathrm{~s}, 4 \mathrm{H}), 6.28(\mathrm{~s}, 4 \mathrm{H}) ;{ }^{13} \mathrm{C}$ NMR $(67.9$ $\left.\mathrm{MHz} \mathrm{CDCl}_{3}\right) \delta 14.36,58.28,72.60,133.30,205.48$; IR $(\mathrm{KBr})$ $1703(C=0), 1457,1382,1355,1300,1186,1106,1070,1020$ $\mathrm{cm}^{-1}$; MS (70 eV) m/z (\%) $416\left(\mathrm{M}^{+}-\mathrm{SO}\right), 268$ (59.0). Anal. Calcd for $\mathrm{C}_{18} \mathrm{H}_{20} \mathrm{O}_{4} \mathrm{~S}_{2}$ : C, 59.32; $\mathrm{H}, 5.53$. Found: $\mathrm{C}, 58.89 ; \mathrm{H}$, 5.69 .

5,5,6,6-Tetracyano-1,4-dimethyl-7-thiabicyclo[2.2.1] 2-ene S-Oxide (11). 1a (200 mg, $1.8 \mathrm{mmol})$ was reacted with $\mathrm{BF}_{3} \cdot \mathrm{Et}_{2} \mathrm{O}(2 \mathrm{~mL}, 16.2 \mathrm{mmol}), \mathrm{m}-\mathrm{CPBA}(400 \mathrm{mg}, 2.3 \mathrm{mmol})$, and TCNE (150 mg, $1.17 \mathrm{mmol}$ ) as described for $\mathbf{3}$ to yield $\mathbf{1 1}$ (290 mg, 63\%): $\mathrm{mp} 235{ }^{\circ} \mathrm{C}$ (dec, from ether); ${ }^{1 \mathrm{H}} \mathrm{NMR}$ (270 $\left.\mathrm{MHz}, \mathrm{CD}_{2} \mathrm{Cl}_{2}\right) \delta 2.06\left(\mathrm{~s}, 6 \mathrm{H}, 2 \mathrm{CH}_{3}\right), 6.53(\mathrm{~s}, 2 \mathrm{H}) ;{ }^{13} \mathrm{C} \mathrm{NMR}$ $\left(67.9 \mathrm{MHz}, \mathrm{CD}_{2} \mathrm{Cl}_{2}\right) \delta 13.10,77.00,107.78,110.37,135.31$; IR (KBr) 1448, 1390, 1090, $1073 \mathrm{~cm}^{-1}$; MS (70 eV) m/z (\%) 256 $\left(\mathrm{M}^{+}\right), 208\left(\mathrm{M}^{+}-\mathrm{SO}, 39.7\right), 193(100)$. Anal. Calcd for $\mathrm{C}_{12} \mathrm{H}_{8} \mathrm{~N}_{4^{-}}$ OS: C, 56.24; H, 3.15; N, 21.86. Found: C, 55.57; H, 3.30; N, 21.16. HRMS $\mathrm{m} / \mathrm{z} \quad \mathrm{C}_{12} \mathrm{H}_{8} \mathrm{~N}_{4} \mathrm{OS}$ : Calcd 256.0415. Found: 256.0419.

5,5,6,6,-Tetracyano-1,2,3,4-tetramethyl-7-thiabicyclo[2.2.1] hept-2-ene S-Oxide (12). 1b (300 mg, $2.14 \mathrm{mmol})$ was reacted with $\mathrm{BF}_{3} \cdot \mathrm{Et}_{2} \mathrm{O}(1.5 \mathrm{~mL}, 11.8 \mathrm{mmol}), \mathrm{m}-\mathrm{CPBA}(480 \mathrm{mg}$, $2.79 \mathrm{mmol}$ ), and TCNE (160 mg, $1.25 \mathrm{mmol}$ ) as described for 3 to give 12 ( $350 \mathrm{mg}, 57 \%$ ): $\mathrm{mp} 258-259^{\circ} \mathrm{C}$ (dec, from ether); ${ }^{1} \mathrm{H}$ NMR $\left(270 \mathrm{MHz} \mathrm{CDCl}_{3}\right) \delta 1.99\left(\mathrm{~s}, 6 \mathrm{H}, 2 \mathrm{CH}_{3}\right), 2.00(\mathrm{~s}, 6 \mathrm{H}$, $\left.2 \mathrm{CH}_{3}\right) ;{ }^{13} \mathrm{C} \mathrm{NMR}\left(67.9 \mathrm{MHz}, \mathrm{CD}_{2} \mathrm{Cl}_{2}\right) \delta 11.54,12.67,52.60$, 78.04, 108.12, 110.31, 135.63; IR (KBr) 1453, 1391, 1117, 1078 $\mathrm{cm}^{-1}$; MS (70 eV) m/z (\%) 236 (M+ - SO, 16.8), 221 (80.5), 194 (40.8).

5-Chloro-5-cyano-1,2,3,4-tetramethyl-7-thiabicyclo[2.2.1]hept-2-ene S-Oxide (14). $1 \mathbf{1 b}(140 \mathrm{mg}, 1.0 \mathrm{mmol})$ was reacted with $\mathrm{BF}_{3} \cdot \mathrm{Et}_{2} \mathrm{O}(0.6 \mathrm{~mL}, 4.73 \mathrm{mmol}), \mathrm{m}-\mathrm{CPBA}(220 \mathrm{mg}, 1.3$ $\mathrm{mmol})$, and 1-chloro-1-cyanoethylene (170 $\mathrm{mg}, 2.0 \mathrm{mmol}$ ) to give 14 (130 mg, 54\%): $\mathrm{mp} 90^{\circ} \mathrm{C}$ (from hexane); ${ }^{1} \mathrm{H}$ NMR (270 $\left.\mathrm{MHz}_{2} \mathrm{CDCl}_{3}\right) \delta 1.47\left(\mathrm{~s}, 3 \mathrm{H}, \mathrm{CH}_{3}\right), 1.76\left(\mathrm{~s}, 3 \mathrm{H}, \mathrm{CH}_{3}\right), 1.83(\mathrm{~s}$, $\left.6 \mathrm{H}, 2 \mathrm{CH}_{3}\right), 2.42(\mathrm{~d}, 1 \mathrm{H}, 2 \mathrm{~J}=14.5 \mathrm{~Hz}), 3.36(\mathrm{~d}, 1 \mathrm{H}, 2 \mathrm{~J}=14.5$ $\mathrm{Hz}$ ); I R (KBr) 2980, 2932, 2234, 1642, 1458, 1386, $1072 \mathrm{~cm}^{-1}$; MS (70 eV) m/z (\%) $243\left(\mathrm{M}^{+}, 6.9\right), 195\left(\mathrm{M}^{+}-\mathrm{SO}, 100\right)$. Anal. Calcd for $\mathrm{C}_{11} \mathrm{H}_{14} \mathrm{NOCIS}$ : C, 54.20; H, 5.79; N, 5.75. Found: C, 54.13; H, 5.81; N, 5.85 .

Dimethyl 1,8-Dimethyl-12-oxa-11-thiatetracyclo[6.2.1.1,6.0 $0^{2,7}$ ]dodeca-4,9-diene-4,5-dicarboxylate 11-0xide (24). Cycloadduct of 2,5-Dimethylthiophene with 1:1 Adduct of Furan with DMAD (23). $\mathrm{BF}_{3} \cdot \mathrm{Et}_{2} \mathrm{O}(2 \mathrm{~mL}, 16.2$ $\mathrm{mmol}$ ) was added to a solution of 2,5-dimethylthiophene (300 $\mathrm{mg}, 2.68 \mathrm{mmol})$ in dry $\mathrm{CH}_{2} \mathrm{Cl}_{2}(10 \mathrm{~mL})$ under an inert atmosphere and at $-20^{\circ} \mathrm{C}$. The mixture was stirred for 10 min at $-20^{\circ} \mathrm{C}$. Thereafter a solution of m-CPBA ( $1.10 \mathrm{~g}, 5.90$ mmol) in $\mathrm{CH}_{2} \mathrm{Cl}_{2}(20 \mathrm{~mL})$ was added dropwise, and the resulting reaction mixture was stirred for $2 \mathrm{~h}$ at $-20^{\circ} \mathrm{C}$. Then the suspension was poured into a mixture of a concd aqueous solution of $\mathrm{NaHCO}_{3}(20 \mathrm{~mL})$ and $\mathrm{CH}_{2} \mathrm{Cl}_{2}(50 \mathrm{~mL})$ and stirred at room temperature for $20 \mathrm{~min}$. The organic phase was separated and the aqueous phase extracted with $\mathrm{CH}_{2} \mathrm{Cl}_{2}(3 \times$ $20 \mathrm{~mL}$ ). The combined organic solution was washed with water and dried over anhydrous $\mathrm{MgSO}_{4} . \quad \mathrm{MgSO}_{4}$ was filtered off, and to the filtrate was added dimethyl 7-oxabicycl o[2.2.1]hepta-2,5-diene-3,4-dicarboxylate (23) $(400 \mathrm{mg}, 3.57 \mathrm{mmol}$ ). The resulting reaction mixture was stirred for $1 \mathrm{~h}$ at ambient temperature. The solvent was evaporated in vacuo, and the resi due was chromatographed on silica gel to yield $\mathbf{2 4}$ (475 mg, $52 \%)$ as colorless crystals.

24: $\mathrm{mp} 110-112^{\circ} \mathrm{C}$ (from ether); ${ }^{1} \mathrm{H} \mathrm{NMR}\left(270 \mathrm{MHz} \mathrm{CDCl}_{3}\right)$ $\delta 1.57\left(\mathrm{~s}, 6 \mathrm{H}, 2 \mathrm{CH}_{3}\right), 3.09(\mathrm{~s}, 2 \mathrm{H}), 3.82\left(\mathrm{~s}, 6 \mathrm{H}, 2 \mathrm{COOCH}_{3}\right)$, $5.03(\mathrm{~s}, 2 \mathrm{H}), 6.02(\mathrm{~s}, 2 \mathrm{H}) ;{ }^{13} \mathrm{C} \mathrm{NMR}\left(67.9 \mathrm{MHz} \mathrm{CDCl}_{3}\right) \delta 15.31$, 52.89, 54.81, 70.68, 82.16, 132.00, 147.15, 162.80; IR (KBr) 1740 (C=O), 1640, 1430, 1220, $1050 \mathrm{~cm}^{-1}$; MS (70 eV) m/z (\%) $232\left(\mathrm{M}^{+}-2\left[\mathrm{C}_{2} \mathrm{H}_{2} \mathrm{O}_{2}\right], 4.3\right), 184$ (232 - SO, 16.2), 153 (69.4), 106 (100). Anal. Calcd for $\mathrm{C}_{16} \mathrm{H}_{18} \mathrm{O}_{6} \mathrm{~S}: \mathrm{C}, 56.79 ; \mathrm{H}, 5.36$. Found: C, 56.79; H, 5.19.
Dimethyl 1,3,8-Trimethyl-12-oxa-11-thiatetracyclo[6.2.1.1 $\left.1^{3,6} .0^{2,7}\right]$ dodeca-4,9-diene-4,5-dicarboxylate 11-0xide (26). la $(200 \mathrm{mg}, 1.79 \mathrm{mmol})$ was reacted with $\mathrm{BF}_{3} \cdot \mathrm{Et}_{2} \mathrm{O}$ (2 mL), m-CPBA (400 mg, $2.32 \mathrm{mmol}$ ), and 25 (320 mg, 1.43 $\mathrm{mmol}$ ) as described for $\mathbf{2 4}$ to produce 26 (330 $\mathrm{mg}, 53 \%): \mathrm{mp}$ 103-105 ${ }^{\circ} \mathrm{C}$ (from ether); ${ }^{1} \mathrm{H}$ NMR $\left(270 \mathrm{MHz} \mathrm{CDCl}_{3}\right) \delta 1.56$ $\left(\mathrm{s}, 3 \mathrm{H}, \mathrm{CH}_{3}\right), 1.60\left(\mathrm{~s}, 3 \mathrm{H}, \mathrm{CH}_{3}\right), 1.61\left(\mathrm{~s}, 3 \mathrm{H}, \mathrm{CH}_{3}\right), 3.08(\mathrm{~d}, 1 \mathrm{H}$, 3 $=7.6 \mathrm{~Hz}), 3.23(\mathrm{~d}, 1 \mathrm{H}, 3 \mathrm{~J}=7.6 \mathrm{~Hz}), 3.79\left(\mathrm{~s}, 3 \mathrm{H}, \mathrm{COOCH}_{3}\right)$, $3.83\left(\mathrm{~s}, 3 \mathrm{H}, \mathrm{COOCH}_{3}\right), 4.92(1 \mathrm{H}, \mathrm{s}), 6.03(\mathrm{~d}, 1 \mathrm{H}, 3 \mathrm{~J}=6.9 \mathrm{~Hz})$, $6.09(\mathrm{~d}, 1 \mathrm{H}, 3 \mathrm{~J}=6.9 \mathrm{~Hz}) ;{ }^{13} \mathrm{C} \mathrm{NMR}\left(67.9 \mathrm{MHz} \mathrm{CDCl}_{3}\right) \delta 14.58$, 15.94 (2C), 52.23 (2C), 55.87, 57.81, 69.42, 70.12, 79.35; 91.12, $130.85,132.06,145.14,151.28,162.05,163.92$; IR (KBr) 1740 $(C=0), 1720(C=0), 1630,1430,1050,1010 \mathrm{~cm}^{-1}$; MS (70 eV) $\mathrm{m} / \mathrm{z}(\%) 246\left(\mathrm{M}^{+}-2\left[\mathrm{C}_{2} \mathrm{H}_{2} \mathrm{O}_{2}\right], 199\right.$ (100). Anal. Calcd for $\mathrm{C}_{17} \mathrm{H}_{20} \mathrm{O}_{6} \mathrm{~S}: \quad \mathrm{C}, 57.94 ; \mathrm{H}, 5.72$. Found: C, 57.76; H, 5.79.

Dimethyl 1,8,9,10-Tetramethyl-12-oxa-11-thiatetracyclo[6.2.1.1 3,6.02,7]dodeca-4,9-diene-4,5-dicarboxylate 11-Oxide (27). $\mathbf{l b}(160 \mathrm{mg}, 1.14 \mathrm{mmol})$ was reacted with $\mathrm{BF}_{3} \cdot \mathrm{Et}_{2} \mathrm{O}$ (2 mL, $16.2 \mathrm{mmol}), \mathrm{m}-\mathrm{CPBA}$ (260 mg, $1.5 \mathrm{mmol}$ ), and 23 (250 $\mathrm{mg}, 1.2 \mathrm{mmol}$ ) as described for 24 to give 27 (260 $\mathrm{mg}, 50 \%$ ): mp $166-168{ }^{\circ} \mathrm{C}$ (from ether); ${ }^{1} \mathrm{H}$ NMR $\left(270 \mathrm{MHz} \mathrm{CDCl}_{3}\right) \delta$ $1.52\left(\mathrm{~s}, 6 \mathrm{H}, 2 \mathrm{CH}_{3}\right), 1.72\left(\mathrm{~s}, 6 \mathrm{H}, 2 \mathrm{CH}_{3}\right), 2.94(\mathrm{~s}, 2 \mathrm{H}), 3.81$ (s, $\left.6 \mathrm{H}, 2 \mathrm{COOCH}_{3}\right), 4.92(\mathrm{~s}, 2 \mathrm{H}) ;{ }^{13} \mathrm{C} \mathrm{NMR}\left(67.9 \mathrm{MHz}, \mathrm{CDCl}_{3}\right) \delta$ 12.33, 13.46, 52.42, 53.78, 70.13, 81.42, 129.67, 147.00, 162.44; IR (KBr) $1720(\mathrm{C}=\mathrm{O}), 1640,1430,1058,990 \mathrm{~cm}^{-1}$; MS (70 eV) $\mathrm{m} / \mathrm{z}(\%) 335$ (4.3), 182 (36.1), 135 (100). Anal. Calcd for $\mathrm{C}_{18} \mathrm{H}_{22} \mathrm{O}_{6} \mathrm{~S}: \mathrm{C}, 59.00 ; \mathrm{H}, 6.05$. Found: C, 58.64; $\mathrm{H}, 6.15$.

Dimethyl 1,3,8,9,10-Pentamethyl-12-oxa-11-thiatetracyclo[6.2.1.13,6.02,7]dodeca-4,9-diene-4,5-dicarboxylate 11Oxide (28). 1 b (160 mg, $1.14 \mathrm{mmol})$ was reacted with $\mathrm{BF}_{3}$. $\mathrm{Et}_{2} \mathrm{O}(2 \mathrm{~mL}, 16.2 \mathrm{mmol}), \mathrm{m}-\mathrm{CPBA}$ (260 mg, $1.5 \mathrm{mmol}$ ), and 25 (260 mg, $1.2 \mathrm{mmol}$ ) is described for 24 to give 28 (230 mg, 53\%): $\mathrm{mp} 125-126^{\circ} \mathrm{C}$ (from ether); ${ }^{1} \mathrm{H}$ NMR $\left(270 \mathrm{MHz} \mathrm{CDCl}_{3}\right.$ ) $\delta 1.48\left(\mathrm{~s}, 3 \mathrm{H}, \mathrm{CH}_{3}\right), 1.55\left(\mathrm{~s}, 3 \mathrm{H}, \mathrm{CH}_{3}\right), 1.59\left(\mathrm{~s}, 3 \mathrm{H} ; \mathrm{CH}_{3}\right), 1.76$ $\left(\mathrm{s}, 3 \mathrm{H}, \mathrm{CH}_{3}\right), 1.84\left(\mathrm{~s}, 3 \mathrm{H}, \mathrm{CH}_{3}\right), 3.01(\mathrm{~d}, 1 \mathrm{H}, 3 \mathrm{~J}=7.6 \mathrm{~Hz}), 3.05$ $(\mathrm{d}, 1 \mathrm{H}, 3 \mathrm{~J}=7.6 \mathrm{~Hz}), 3.78\left(\mathrm{~s}, 3 \mathrm{H}, \mathrm{COOCH}_{3}\right), 3.82(\mathrm{~s}, 3 \mathrm{H}$, $\left.\mathrm{COOCH}_{3}\right), 4.82(\mathrm{~s}, 1 \mathrm{H}) ;{ }^{13} \mathrm{C} \mathrm{NMR}\left(67.9 \mathrm{MHz} \mathrm{CDCl}_{3}\right) \delta 12.54$, $12.60,13.39,14.72,15.36,52.33,52.36,55.27,58.22$, 69.38, 70.96, 79.17, 91.07, 129.34, 131.19, 145.35, 150.71, 162.12, 164.11; IR (KBr) $1710(\mathrm{C}=0)$ and $1058 \mathrm{~cm}^{-1}$; MS (70 eV) m/z (\%) 199 (9.7), 167 (17.3), 135 (100). Anal. Calcd for $\mathrm{C}_{19} \mathrm{H}_{24} \mathrm{O}_{6} \mathrm{~S}: \mathrm{C}, 59.98 ; \mathrm{H}, 6.36$. Found: C, 59.95; $\mathrm{H}, 6.42$.

1,7-Dimethyl-10-thiatricyclo[5.2.1.0 $\left.0^{2,6}\right]$ dec-8-en-3-one 10Oxide (30a). $B F_{3} \cdot E_{2} \mathrm{O}-C a t a l y z e d$ Cycloaddition of 2,5Dimethylthiophene with Cyclopent-2-enone (29a). $\mathrm{BF}_{3}$. $\mathrm{Et}_{2} \mathrm{O}$ (2 mL) was added to a solution of 2,5-dimethylthiophene (300 $\mathrm{mg}, 2.68 \mathrm{mmol}$ ) and cyclopent-2-enone (29a) $(0.45 \mathrm{~mL}$, $5.4 \mathrm{mmol}$ ) in $\mathrm{CH}_{2} \mathrm{Cl}_{2}(15 \mathrm{~mL})$ under an inert atmosphere and at $-20^{\circ} \mathrm{C}$. The reaction mixture was stirred for $10 \mathrm{~min}$ at $-20{ }^{\circ} \mathrm{C}$. Then a solution of m-CPBA (700 mg, $\left.4.05 \mathrm{mmol}\right)$ in dry $\mathrm{CH}_{2} \mathrm{Cl}_{2}(15 \mathrm{~mL})$ was added slowly. The reaction mixture was stirred for another $4 \mathrm{~h}$ at $-20^{\circ} \mathrm{C}$. Then the suspension was poured into a mixture of a concd aqueous solution of $\mathrm{NaHCO}_{3}(30 \mathrm{~mL})$ and $\mathrm{CH}_{2} \mathrm{Cl}_{2}(50 \mathrm{~mL})$. The resulting mixture was stirred for $20 \mathrm{~min}$ at room temperature. The organic phase was separated, and the aqueous phase was extracted with $\mathrm{CH}_{2} \mathrm{Cl}_{2}(3 \times 20 \mathrm{~mL})$. The combined organic phase was washed with water and brine and dried over anhydrous $\mathrm{MgSO}_{4}$. After removal of the solvent in vacuo, the residue was chromatographed on silica gel to give $30 \mathrm{a}$ (200 $\mathrm{mg}, 36 \%)$ as a colorless oil. 30a: ${ }^{1} \mathrm{H}$ NMR $\left(270 \mathrm{MHz} \mathrm{CDCl}_{3}\right) \delta 1.53(\mathrm{~s}, 3 \mathrm{H}$, $\left.\mathrm{CH}_{3}\right), 1.64\left(\mathrm{~s}, 3 \mathrm{H}, \mathrm{CH}_{3}\right), 1.67-2.28(\mathrm{~m}, 4 \mathrm{H}), 3.21(\mathrm{~d}, 1 \mathrm{H}, \mathrm{J}=$ $9.4 \mathrm{~Hz}$ ), 3.46 (ddd, $1 \mathrm{H}$, J = $3.4 \mathrm{~Hz}, 9.4 \mathrm{~Hz}, 9.7 \mathrm{~Hz}$ ), 6.08 (d, $\left.1 \mathrm{H},{ }^{3} \mathrm{~J}=7.1 \mathrm{~Hz}\right), 6.12\left(\mathrm{~d}, 1 \mathrm{H}, 3^{3}=7.1 \mathrm{~Hz}\right) ;{ }^{13} \mathrm{C}$ NMR $(67.9$ $\left.\mathrm{MHz} \mathrm{CDCl}_{3}\right) \delta 13.78,14.18,19.64,41.53,46.27,57.43,73.46$, 73.64, 132.95, 133.67, 218.29; IR (neat) $1720(\mathrm{C}=\mathrm{O})$ and 1060 $\mathrm{cm}^{-1}$; MS (70 eV) m/z (\%) $210\left(\mathrm{M}^{+}, 8.4\right)$ and 164 (19.5).

1,7,8,9-Tetramethyl-10-thiatricyclo[5.2.1.02,6]dec-8-en3-one 10-Oxide (30b). Cycloaddition of 2,3,4,5-Tetramethylthiophene with Cyclopent-2-enone (29a). 39b: (190 mg, 28\%): $\mathrm{mp} 106-107{ }^{\circ} \mathrm{C}$ (from ether); ${ }^{1} \mathrm{H}$ NMR (270 $\left.\mathrm{MHz}_{2} \mathrm{CDCl}_{3}\right) \delta 1.49\left(\mathrm{~s}, 3 \mathrm{H}, \mathrm{CH}_{3}\right), 1.59\left(\mathrm{~s}, 3 \mathrm{H}, \mathrm{CH}_{3}\right), 1.67(\mathrm{~s}$, $\left.3 \mathrm{H}, \mathrm{CH}_{3}\right), 1.80\left(\mathrm{~s}, 3 \mathrm{H}, \mathrm{CH}_{3}\right), 1.97-2.29(\mathrm{~m}, 4 \mathrm{H}), 3.06\left(\mathrm{~d},{ }^{1} \mathrm{H}, \mathrm{J}\right.$ $=9,5 \mathrm{~Hz}$ ), 3.47 (ddd, $1 \mathrm{H}, \mathrm{J}=3.8 \mathrm{~Hz}, 9.5 \mathrm{~Hz}, 9.5 \mathrm{~Hz}$ ); ${ }^{13} \mathrm{C} \mathrm{NMR}$ $\left(67.9 \mathrm{MHz} \mathrm{CDCl}_{3}\right) \delta 13.19,13.50,13.71,18.94,67.57,72.27$, 73.69, 75.87, 126.70, 127.15, 129.11, 134.93, 145.59; IR (KBr) 
$1729(\mathrm{C}=\mathrm{O}), 1464,1440,1189,1165,1104,1060,959 \mathrm{~cm}^{-1}$. MS (70 eV) m/z (\%) $238\left(\mathrm{M}^{+}, 4.4\right), 191$ (75.3), 172 (53.5), 148 (100). Anal. Calcd for $\mathrm{C}_{13} \mathrm{H}_{18} \mathrm{O}_{2} \mathrm{~S}: \mathrm{C}, 65.51 ; \mathrm{H}, 7.61$. Found: C, $65.41 ; \mathrm{H}, 7.65$.

1,8-Dimethyl-11-thiatricyclo[6.2.1.02,7]undec-9-en-3one 11-Oxide (30c). Cycloaddition of 2,5-Dimethylthiophene with Cyclohex-2-enone (29b). 30c: (90 mg, 8\%): $\mathrm{mp}$ 80-82 ${ }^{\circ} \mathrm{C}$ (from ether/hexane); ${ }^{1} \mathrm{H}$ NMR (270 $\left.\mathrm{MHz} \mathrm{CDCl}_{3}\right) \delta$ $1.49\left(\mathrm{~s}, 3 \mathrm{H}, \mathrm{CH}_{3}\right), 1.71\left(\mathrm{~s}, 3 \mathrm{H}, \mathrm{CH}_{3}\right), 2.08-2.60(\mathrm{~m}, 6 \mathrm{H}), 3.24$ $(\mathrm{d}, 1 \mathrm{H}, \mathrm{J}=3.9 \mathrm{~Hz}), 3.28(\mathrm{~d}, 1 \mathrm{H}, \mathrm{J}=3.9 \mathrm{~Hz}), 5.82(\mathrm{~d}, 1 \mathrm{H}, 3 \mathrm{~J}=$ $6.9 \mathrm{~Hz}), 6.20(\mathrm{~d}, 1 \mathrm{H}, 3 \mathrm{~J}=6.9 \mathrm{~Hz}) ;{ }^{13} \mathrm{C} \mathrm{NMR}\left(67.9 \mathrm{MHz}^{3} \mathrm{CDCl}_{3}\right)$ $\delta$ 13.68, 15.29, 21.71, 23.92, 38.87, 45.45, 55.42, 71.18, 71.43, 131.12, 135.42, 212.09; IR (KBr) $1700(\mathrm{C}=0), 1440,1380,1350$, 1290, 1150, 1080, $900 \mathrm{~cm}^{-1}$; MS (70 eV) m/z (\%) $224\left(\mathrm{M}^{+}, 3\right)$ and $176\left(\mathrm{M}^{+}-\mathrm{SO}, 100\right)$. Anal. Calcd for $\mathrm{C}_{12} \mathrm{H}_{16} \mathrm{O}_{2} \mathrm{~S}: \mathrm{C}, 64.25$; $H, 7.19$. Found: C, 64.08; $H, 6.87$.

1,8,9,10-Tetramethyl-11-thiatricyclo[6.2.1.02,7]undec-9en-3-one 11-Oxide (30d). Cycloaddition of 2,3,4,5-Dimethylthiophene with Cyclohex-2-enone (29b). 30d: (170 mg, 25\%): $\mathrm{mp} 132-133{ }^{\circ} \mathrm{C}$ (from ether); ${ }^{1} \mathrm{H}$ NMR $(270 \mathrm{MHz}$, $\left.\mathrm{CDCl}_{3}\right) \delta 1.48\left(\mathrm{~s}, 3 \mathrm{H}, \mathrm{CH}_{3}\right), 1.66\left(\mathrm{~s}, 3 \mathrm{H}, \mathrm{CH}_{3}\right), 1.68\left(\mathrm{~s}, 3 \mathrm{H}, \mathrm{CH}_{3}\right)$, $1.79\left(\mathrm{~s}, 3 \mathrm{H}, \mathrm{CH}_{3}\right), 1.89-2.41(\mathrm{~m}, 6 \mathrm{H}), 3.17(\mathrm{~m}, 1 \mathrm{H}), 3.18(\mathrm{~m}$, $1 \mathrm{H}) ;{ }^{13} \mathrm{C} \mathrm{NMR}\left(67.9 \mathrm{MHz} \mathrm{CDCl}_{3}\right) \delta 12.35,12.42,12.62,14.02$, 21.78, 23.67, 39.01, 46.51, 55.10, 71.81, 72.04, 130.93, 134.47, 212.70; IR (KBr) $1698(\mathrm{C}=0), 1445,1376,1057,1027,878$ $\mathrm{cm}^{-1}$; MS (70 eV) m/z (\%) $252\left(\mathrm{M}^{+}, 12.9\right), 203$ (42.6), 161 (82.3). Anal. Calcd for $\mathrm{C}_{14} \mathrm{H}_{20} \mathrm{O}_{2} \mathrm{~S}$ : C, 66.63; $\mathrm{H}$, 7.99. Found: C, 66.75; H, 8.01 .

1,9,10,11-Tetramethyl-12-thiatricyclo[7.2.1.02,8]dodec10-en-3-one 12-Oxide (30e). Cycloaddition of 2,3,4,5Tetramethylthiophene with Cyclohept-2-enone (29c). 30e: (140 mg, 25\%): $\mathrm{mp} 115-117^{\circ} \mathrm{C}$ (from ether); ${ }^{1} \mathrm{H}$ NMR $\left(270 \mathrm{MHz}_{2} \mathrm{CDCl}_{3}\right) \delta 0.80-0.85(\mathrm{~m}, \mathrm{H}), 1.42\left(\mathrm{~s}, 3 \mathrm{H}, \mathrm{CH}_{3}\right), 1.46$ $\left(\mathrm{s}, 3 \mathrm{H}, \mathrm{CH}_{3}\right), 1.57(\mathrm{~m}, 1 \mathrm{H}), 1.65\left(\mathrm{~s}, 3 \mathrm{H}, \mathrm{CH}_{3}\right), 1.71(\mathrm{~m}, 1 \mathrm{H})$, $1.79(\mathrm{~m}, 1 \mathrm{H}), 1.90\left(\mathrm{~s}, 3 \mathrm{H}, \mathrm{CH}_{3}\right), 2.32(\mathrm{~m}, 1 \mathrm{H}), 2.51(\mathrm{~m}, 1 \mathrm{H})$, 2.82 (ddd, $1 \mathrm{H}, \mathrm{J}=1.5 \mathrm{~Hz}, 11.5 \mathrm{~Hz}, 11.5 \mathrm{~Hz}), 3.78(\mathrm{~d}, 1 \mathrm{H}, \mathrm{J}=$ $10.0 \mathrm{~Hz}) ;{ }^{13} \mathrm{C} N \mathrm{NMR}\left(67.9 \mathrm{MHz} \mathrm{CDCl}_{3}\right) \delta 12.37,12.47(2 \mathrm{C})$, 13.34, 23.52, 25.27, 27.14, 43.65, 45.61, 60.58, 70.41, 71.66, $129.58,133.76,210.80$; I R ( KBr) 2880, $1703(\mathrm{C}=0), 1456,1134$, 1095, $1056 \mathrm{~cm}^{-1}$; MS (70 eV) m/z (\%) $266\left(\mathrm{M}^{+}, 3\right), 218$ (100), 190 (16). Anal. Calcd for $\mathrm{C}_{15} \mathrm{H}_{22} \mathrm{O}_{2} \mathrm{~S}$ : C, 67.63; $\mathrm{H}, 8.32$. Found: C, 67.52; $\mathrm{H}, 8.28$.

$\mathrm{BF}_{3}$-Catalyzed Oxidation of Dimethylthiophene (1a) in the Absence of Additional Dienophiles. $\mathrm{BF}_{3} \cdot \mathrm{Et}_{2} \mathrm{O}(2.0$ $\mathrm{mL}, 16.1 \mathrm{mmol}$ ) was added to a solution of 2,5-dimethylthiophene (400 mg, $3.57 \mathrm{mmol})$ in dry $\mathrm{CH}_{2} \mathrm{Cl}_{2}(10 \mathrm{~mL})$ under an inert atmosphere and at $-20^{\circ} \mathrm{C}$. The reaction mixture was stirred for $10 \mathrm{~min}$ at $-20^{\circ} \mathrm{C}$. Then a solution of $\mathrm{m}$-CPBA $(900$ $\mathrm{mg}, 5.20 \mathrm{mmol})$ in dry $\mathrm{CH}_{2} \mathrm{Cl}_{2}(20 \mathrm{~mL})$ was added slowly. The reaction mixture was stirred for another $2 \mathrm{~h}$ at $-20^{\circ} \mathrm{C}$. Then the suspension was poured into a mixture of a concd aqueous solution of $\mathrm{NaHCO}_{3}(20 \mathrm{~mL})$ and $\mathrm{CH}_{2} \mathrm{Cl}_{2}(50 \mathrm{~mL})$. The resulting mixture was stirred for $20 \mathrm{~min}$ at room temperature. The organic phase was separated, and the aqueous phase was extracted with $\mathrm{CH}_{2} \mathrm{Cl}_{2}(3 \times 20 \mathrm{~mL})$. The combined organic phase was washed with water and brine and dried over anhydrous $\mathrm{MgSO}_{4}$. After removal of the solvent in vacuo, the residue was chromatographed on silica gel to give $\mathbf{3 2 a}-\mathbf{c}$.

1,2,4,7-Tetramethyl-3,10-dithiatricyclo[5.2.1.02,6]deca4,8-diene 3,3,10-Trioxide (32a) (49 mg, 12\%): $R_{f} 0.40$ (ether); $\mathrm{mp} 176-178{ }^{\circ} \mathrm{C}$ (dec, from benzene); ${ }^{1} \mathrm{H}$ NMR $(270 \mathrm{MHz}$, $\left.\mathrm{CDCl}_{3}\right) \delta 1.57\left(\mathrm{~s}, 3 \mathrm{H}, \mathrm{CH}_{3}\right), 1.74\left(\mathrm{~s}, 3 \mathrm{H}, \mathrm{CH}_{3}\right), 1.87\left(\mathrm{~s}, 3 \mathrm{H}, \mathrm{CH}_{3}\right)$, $2.00\left(\mathrm{~s}, 3 \mathrm{H}, \mathrm{CH}_{3}\right), 3.65(\mathrm{bs}, 1 \mathrm{H}), 5.81(\mathrm{~d}, 1 \mathrm{H}, 3 \mathrm{~J}=6.9 \mathrm{~Hz}), 6.04$ (bs, $1 \mathrm{H}), 6.25(\mathrm{~d}, 1 \mathrm{H}, 3 \mathrm{~J}=6.9 \mathrm{~Hz}) ;{ }^{13} \mathrm{C} \mathrm{NMR}\left(67.9 \mathrm{MHz} \mathrm{CDCl}_{3}\right)$ $\delta$ 9.60, 12.36, 13.46, 15.94, 61.24, 70.62, 71.93, 73.46, 127.58, 127.84, 136.15, 142.43; IR (KBr) 1440, 1284, 1146, 1079, 1058 $\mathrm{cm}^{-1}$; MS (70 eV) m/z (\%) $224\left(\mathrm{M}^{+}-\mathrm{SO}, 21.7\right), 160$ (20.1), 145 (93.4). Anal. Calcd for $\mathrm{C}_{12} \mathrm{H}_{16} \mathrm{O}_{3} \mathrm{~S}_{2}: \mathrm{C}, 52.92 ; \mathrm{H}, 5.92$. Found: C, 52.86; $\mathrm{H}, 6.04$.

1,2,4,7-Tetramethyl-3,10-dithiatricyclo[5.2.1.02,6]deca4,8-diene 3,10-Dioxide (32b) $(84 \mathrm{mg}, 0.33 \mathrm{mmol}, 18 \%): R_{f}$ 0.30 (ether/MeOH 20:1); $\mathrm{mp} 128-130{ }^{\circ} \mathrm{C}$ (from ether); ${ }^{1} \mathrm{H}$ NMR $\left(270 \mathrm{MHz}_{2} \mathrm{CDCl}_{3}\right) \delta 1.52\left(\mathrm{~s}, 3 \mathrm{H}, \mathrm{CH}_{3}\right), 1.68\left(\mathrm{~s}, 3 \mathrm{H}, \mathrm{CH}_{3}\right), 1.77$ $\left(\mathrm{s}, 3 \mathrm{H}, \mathrm{CH}_{3}\right), 2.01\left(\mathrm{~s}, 3 \mathrm{H}, \mathrm{CH}_{3}\right), 3.78(\mathrm{bs}, 1 \mathrm{H}), 5.63(\mathrm{~d}, 1 \mathrm{H}, 3 \mathrm{~J}=$ $6.6 \mathrm{~Hz}), 5.86(\mathrm{bs}, 1 \mathrm{H}), 6.27\left(\mathrm{~d}, 1 \mathrm{H},{ }^{3} \mathrm{~J}=6.6 \mathrm{~Hz}\right) ;{ }^{13} \mathrm{C} \mathrm{NMR}(67.9$ $\left.\mathrm{MHz}_{2} \mathrm{CDCl}_{3}\right) \delta 13.19,13.50,13.71,18.94,67.57,72.27,73.69$,
75.87, 126.70, 127.15, 129.11, 134.93, 145.59; IR (KBr) 1642, $1441,1373,1352,1277,1263,1081,1059,1038 \mathrm{~cm}^{-1}$; MS (70 eV) $\mathrm{m} / \mathrm{z}(\%) 256\left(\mathrm{M}^{+}, 10.3\right), 208\left(\mathrm{M}^{+}-\mathrm{SO}, 63.4\right), 191$ (100), 176 (50.6), 159 (41.9). Anal. Calcd for $\mathrm{C}_{12} \mathrm{H}_{16} \mathrm{O}_{2} \mathrm{~S}_{2}$ : C, 56.22; $H, 6.29$. Found: $C, 56.09 ; \mathrm{H}, 6.32$.

1,2,4,7-Tetramethyl-3,10-dithiatricyclo[5.2.1.02,6]deca4,8-diene 3,10-Dioxide (32c) (82 gm, $0.32 \mathrm{mmol}, 18 \%): R_{f}$ 0.11 (ether/MeOH 20:1); $\mathrm{mp} 159{ }^{\circ} \mathrm{C}$ (from ether); ${ }^{1} \mathrm{H} N M R$ $\left(\mathrm{CDCl}_{3}, 270 \mathrm{MHz}\right) \delta 1.52\left(\mathrm{~s}, 3 \mathrm{H}, \mathrm{CH}_{3}\right), 1.69\left(\mathrm{~s}, 3 \mathrm{H}, \mathrm{CH}_{3}\right), 1.73$ $\left(\mathrm{s}, 3 \mathrm{H}, \mathrm{CH}_{3}\right), 2.02\left(\mathrm{~s}, 3 \mathrm{H}, \mathrm{CH}_{3}\right), 4.03(\mathrm{~s}, 1 \mathrm{H}), 6.00(\mathrm{~d}, 1 \mathrm{H}, 3 \mathrm{j}=$ $6.9 \mathrm{~Hz}), 6.02(\mathrm{~s}, 1 \mathrm{H}), 6.12(\mathrm{~d}, 1 \mathrm{H}, 3 \mathrm{~J}=6.9 \mathrm{~Hz}) ;{ }^{13} \mathrm{C}$ NMR $(67.9$ $\left.\mathrm{MHz} \mathrm{CDCl}_{3}\right) \delta 12.89,12.98,13.70,14.20,69.29,71.12,72.33$ 81.82, 131.07, 133.78, 133.89, 145.48; IR (KBr) 1650, 1439, 1359, 1184, 1081, 1040, $906 \mathrm{~cm}^{-1}$; MS (70 eV) m/z (\%) $256\left(\mathrm{M}^{+}\right.$, 1.3), 208 (M+ - SO, 28.0), 191 (100), 176 (100), 159 (72.0). Anal. Calcd for $\mathrm{C}_{12} \mathrm{H}_{16} \mathrm{O}_{2} \mathrm{~S}_{2}$ : C, 56.22; $\mathrm{H}, 6.29$. Found: $\mathrm{C}, 56.12 ; \mathrm{H}$, 6.34.

4,7-Dimethylindanone (34): $\mathrm{mp} 71-72{ }^{\circ} \mathrm{C}$ (lit. $\left.78{ }^{\circ} \mathrm{C}\right)^{32}$ (from hexane); ${ }^{1} \mathrm{H}$ NMR $\left(270 \mathrm{MHz}_{2} \mathrm{CDCl}_{3}\right) \delta 2.31\left(\mathrm{~s}, 3 \mathrm{H}, \mathrm{CH}_{3}\right)$, $2.60\left(\mathrm{~s}, 3 \mathrm{H}, \mathrm{CH}_{3}\right), 2.65(\mathrm{t}, 2 \mathrm{H}, 3 \mathrm{~J}=5.6 \mathrm{~Hz}), 2.98(\mathrm{t}, 2 \mathrm{H}, 3 \mathrm{~J}=$ $5.6 \mathrm{~Hz}), 7.00(\mathrm{~d}, 1 \mathrm{H}, 3 \mathrm{~J}=7.7 \mathrm{~Hz}), 7.25(\mathrm{~d}, 1 \mathrm{H}, 3 \mathrm{~J}=7.7 \mathrm{~Hz})$; ${ }^{13} \mathrm{C}$ NMR $\left(67.9 \mathrm{MHz}, \mathrm{CDCl}_{3}\right) \delta 17.39,17.99,24.28,36.66$, $126.20,132.79,134.19,134.39,135.95,154.80,208.46$; IR (KBr) $1700(\mathrm{C}=0), 1580,1490,1440,1380,1320,1240,820 \mathrm{~cm}^{-1}$; MS (70 eV) m/z (\%) $160\left(\mathrm{M}^{+}, 100\right)$. HRMS m/z $\mathrm{C}_{11} \mathrm{H}_{14} \mathrm{O}_{2} \mathrm{~S}$ Anal. Calcd: 210.7150. Found: 210.7170.

5,8-Dimethyltetralone (35): $\mathrm{mp} 29-30^{\circ} \mathrm{C}$ (lit. $31.5^{\circ} \mathrm{C}$ ) ${ }^{33}$ (from hexane); ${ }^{1 \mathrm{H}} \mathrm{NMR}\left(270 \mathrm{MHz}^{\mathrm{C}} \mathrm{CDCl}_{3}\right) \delta 2.11(\mathrm{~m}, 2 \mathrm{H}), 2.63$ $(\mathrm{t}, 2 \mathrm{H}, 3 \mathrm{~J}=6.3 \mathrm{~Hz}), 2.84(\mathrm{t}, 2 \mathrm{H}, 3 \mathrm{~J}=6.3 \mathrm{~Hz}), 6.98(\mathrm{~d}, 1 \mathrm{H}, 3 \mathrm{~J}$ $=7.8 \mathrm{~Hz}), 7.20\left(\mathrm{~d}, 1 \mathrm{H},{ }^{3} \mathrm{~J}=7.8 \mathrm{~Hz}\right)$. Anal. Calcd for $\mathrm{C}_{12} \mathrm{H}_{14} \mathrm{O}: \mathrm{C}, 82.72 ; \mathrm{H}, 8.10$. Found: $\mathrm{C}, 82.53 ; \mathrm{H}, 8.11$.

4,7-Dimethyl-3,10-dithiatricyclo[5.2.1.02,6]deca-4,8-diene 3,10-Dioxide (36). In an inert atmosphere and at -20 ${ }^{\circ} \mathrm{C}, \mathrm{BF}_{3} \cdot \mathrm{Et}_{2} \mathrm{O}(1.5 \mathrm{~mL}, 12.2 \mathrm{mmol})$ was added to a solution of 2-methylthiophene (300 mg, $3.06 \mathrm{mmol}$ ) in dry $\mathrm{CH}_{2} \mathrm{Cl}_{2}(10 \mathrm{~mL})$. The reaction mixture was stirred for $10 \mathrm{~min}$ at $-20^{\circ} \mathrm{C}$. Then a solution of m-CPBA (680 mg, $3.95 \mathrm{mmol}$ ) in dry $\mathrm{CH}_{2} \mathrm{Cl}_{2}$ (15 $\mathrm{mL}$ ) was added slowly. The reaction mixture was stirred at $-20^{\circ} \mathrm{C}$ for another $3 \mathrm{~h}$. Then the suspension was poured into a mixture of concd aqueous $\mathrm{NaHCO}_{3}$ solution $(20 \mathrm{~mL})$ and $\mathrm{CH}_{2-}$ $\mathrm{Cl}_{2}(50 \mathrm{~mL})$ and stirred for $20 \mathrm{~min}$ at ambient temperature. The organic phase was separated, and the aqueous phase was extracted with $\mathrm{CH}_{2} \mathrm{Cl}_{2}(3 \times 20 \mathrm{~mL})$. The combined organic phase was washed with water and brine and dried over anhydrous $\mathrm{MgSO}_{4}$. After removal of the solvent in vacuo, the residue was chromatographed on silica gel to yield $\mathbf{3 6}$ (140 mg, $40 \%$ ) as colorless crystals. $36: \mathrm{mp} 148-149^{\circ} \mathrm{C}$ (from benzene/ hexane, dec): ${ }^{1} \mathrm{H} N M R\left(270 \mathrm{MHz} \mathrm{CDCl}_{3}\right) \delta 1.63\left(\mathrm{~s}, 3 \mathrm{H}, \mathrm{CH}_{3}\right)$ $2.10(\mathrm{dd}, 3 \mathrm{H}, \mathrm{J}=1.6 \mathrm{~Hz}, 2.0 \mathrm{~Hz}), 3.96(\mathrm{~m}, 1 \mathrm{H}), 4.07(\mathrm{dd}, 1 \mathrm{H}$, $\mathrm{J}=4.1 \mathrm{~Hz}, 4.3 \mathrm{~Hz}), 4.82(\mathrm{dd}, 1 \mathrm{H}$, J $=4.1 \mathrm{~Hz}, 7.9 \mathrm{~Hz}), 5.80(\mathrm{~d}$, $1 \mathrm{H}, \mathrm{J}=6.8 \mathrm{~Hz}), 5.82(\mathrm{~m}, 1 \mathrm{H}), 6.37(\mathrm{dd}, 1 \mathrm{H}, \mathrm{J}=4.1 \mathrm{~Hz}, 6.8$ $\mathrm{Hz}) ;{ }^{13} \mathrm{C} \mathrm{NMR}\left(67.9 \mathrm{MHz} \mathrm{CDCl}_{3}\right) \delta 13.41,13.73,57.23,62.71$ $62.80,75.02,127.51,127.69,130.10,147.46$. IR (KBr) 1640, $1570,1440,1380,1342,1310,1280,1262,1210,1150,1110$, $1098,1070,1030 \mathrm{~cm}^{-1}$; MS (70 eV) m/z (\%) $228\left(\mathrm{M}^{+}, 1.5\right), 180$ $\left(\mathrm{M}^{+}-\mathrm{SO}, 22.8\right), 163$ (100). Anal. Calcd for $\mathrm{C}_{15} \mathrm{H}_{20} \mathrm{O}_{2} \mathrm{~S}_{2}: \mathrm{C}$, 52.60; $H, 5.30$. Found: $C, 52.76 ; H, 5.38$.

2,3,4,5-Tetramethylthiophene S-Oxide (31b). $\mathrm{BF}_{3} \cdot \mathrm{Et}_{2} \mathrm{O}$ (1.5 $\mathrm{mL}, 12.2 \mathrm{mmol}$ ) was added to a solution of $2,3,4,5-$ tetramethylthiophene ( $300 \mathrm{mg}, 2.78 \mathrm{mmol}$ ) in dry $\mathrm{CH}_{2} \mathrm{Cl}_{2}$ (10 $\mathrm{mL}$ ) under an inert atmosphere and at $-20^{\circ} \mathrm{C}$. The reaction mixture was stirred for $10 \mathrm{~min}$ at $-20^{\circ} \mathrm{C}$. Then a solution of m-CPBA (480 mg, $2.78 \mathrm{mmol})$ in dry $\mathrm{CH}_{2} \mathrm{Cl}_{2}(10 \mathrm{~mL})$ was added slowly. The reaction mixture was stirred for another 2 $\mathrm{h}$ at $-20^{\circ} \mathrm{C}$. Then the suspension was poured into a mixture of a concd aqueous solution of $\mathrm{NaHCO}_{3}(20 \mathrm{~mL})$ and $\mathrm{CH}_{2} \mathrm{Cl}_{2}$ $(50 \mathrm{~mL})$. The resulting mixture was stirred for $20 \mathrm{~min}$ at room temperature. The organic phase was separated, and the aqueous phase was extracted with $\mathrm{CH}_{2} \mathrm{Cl}_{2}(3 \times 20 \mathrm{~mL})$. The

(32) Mayer, F.; Müller, P. Chem. Ber. Dtsch. Ges. 1927, 60, 22782283.

(33) (a) de Barry Barnett, E.; Sanders, F. G. J . Chem. Soc. 1933 434-437. (b) Eisenbaum, E. J ; Hinman, C. W.; Springer, J. M. Burnham, J. W.; Chou, T. S.; Flanagan, P. W.; Hamming, M. C. J . Org. Chem. 1971, 36, 2480-2485. 
combined organic phase was washed with water and brine and dried over anhydrous $\mathrm{MgSO}_{4}$. After removal of the solvent in vacuo (bath temperature should not exceed $30^{\circ} \mathrm{C}$ ) the resi due was flash-chromatographed on silica gel to give $\mathbf{3 1 b}(250 \mathrm{mg}$, 74\%) as col orless crystals. 31b: $R_{f} 0.30$ (ether); $\mathrm{mp}$ 122-124 ${ }^{\circ} \mathrm{C}$ (from ether); ${ }^{1} \mathrm{H}$ NMR $\left(270 \mathrm{MHz} \mathrm{CDCl}_{3}\right) \delta 2.25(\mathrm{~s}, 6 \mathrm{H}, 2$ $\left.\mathrm{CH}_{3}\right), 2.17\left(\mathrm{~s}, 6 \mathrm{H}, 2 \mathrm{CH}_{3}\right) ;{ }^{13} \mathrm{C} \mathrm{NMR}\left(67.9 \mathrm{MHz}_{1} \mathrm{CDCl}_{3}\right) \delta 10.22$, 12.67, 137.45, 139.53; IR (KBr) 2910, 1640, 1440, 1380, 1210, 1130, $1030 \mathrm{~cm}^{-1}$; MS (70 eV) m/z (\%) $156\left(\mathrm{M}^{+}, 10.8\right), 141$ (16.3), 123 (77.4). HRMS m/z C ${ }_{8} \mathrm{H}_{12} \mathrm{OS}$ : Calcd 156.0605. Found: 156.0604 .

3,4-Dibenzyl-1,2-dimethylthiophene S-Oxide (31c). 31c: (160 mg, 74\%); mp $111-112{ }^{\circ} \mathrm{C}$ (from ether); ${ }^{1} \mathrm{H}$ NMR (270 $\left.\mathrm{MHz} \mathrm{CDCl}_{3}\right) \delta 2.25\left(\mathrm{~s}, 6 \mathrm{H}, 2 \mathrm{CH}_{3}\right), 3.47(\mathrm{~s}, 4 \mathrm{H}), 7.03(\mathrm{~m}, 4 \mathrm{H})$, 7.21-7.27 (m, 6H); ${ }^{13} \mathrm{C}$ NMR $\left(67.9 \mathrm{MHz}, \mathrm{CDCl}_{3}\right) \delta 10.60,32.27$, $127.80,127.92,128.84,137.21,138.52,143.09$; I R (KBr) 1600, 1500, 1450, 1290, $1040 \mathrm{~cm}^{-1}$; MS (70 eV) m/z (\%) $308\left(\mathrm{M}^{+}\right.$, 42.4), 277 (100), 242 (85.9), 218 (76.5). Anal. Calcd for $\mathrm{C}_{20} \mathrm{H}_{20^{-}}$ OS: C, 77.88; H, 6.54. Found: C, 77.61; H, 6.69.

Lewis Acid Catalyzed Oxidation of Bis(2,4,5-trimethylthien-3-yl)methane (38). $\mathrm{BF}_{3} \cdot \mathrm{Et}_{2} \mathrm{O}(1.5 \mathrm{~mL}, 12.2 \mathrm{mmol})$ was added to a solution of $\mathbf{3 8}(330 \mathrm{mg}, 1.25 \mathrm{mmol})$ in dry $\mathrm{CH}_{2^{-}}$ $\mathrm{Cl}_{2}(10 \mathrm{~mL})$ under an inert atmosphere and at $-20^{\circ} \mathrm{C}$. The reaction mixture was stirred for $10 \mathrm{~min}$ at $-20^{\circ} \mathrm{C}$. Then a solution of m-CPBA (760 mg, $4.40 \mathrm{mmol})$ in dry $\mathrm{CH}_{2} \mathrm{Cl}_{2}(20$ $\mathrm{mL}$ ) was added slowly. The reaction mixture was stirred for another $2 \mathrm{~h}$ at $-20^{\circ} \mathrm{C}$. Then the suspension was poured into a mixture of a concd aqueous solution of $\mathrm{NaHCO}_{3}(20 \mathrm{~mL})$ and $\mathrm{CH}_{2} \mathrm{Cl}_{2}(50 \mathrm{~mL})$. The resulting mixture was stirred for $20 \mathrm{~min}$ at room temperature. The organic phase was separated, and the aqueous phase was extracted with $\mathrm{CH}_{2} \mathrm{Cl}_{2}(3 \times 20 \mathrm{~mL})$. The combined organic phase was washed with water and brine and dried over anhydrous $\mathrm{MgSO}_{4}$. After removal of the solvent in vacuo the residue was chromatographed on silica gel to give 39 and 40.

Bis(2,4,5-trimethylthien-3-yl)methane S-Oxide (39) (180 $\mathrm{mg}, 52 \%$ ): as colorless crystals; $\mathrm{R}_{\mathrm{f}} 0.32$ (ether); $\mathrm{mp} 117-118$ ${ }^{\circ} \mathrm{C}$ (from ether); ${ }^{1 \mathrm{H}} \mathrm{NMR}\left(270 \mathrm{MHz} \mathrm{CDCl}_{3}\right) \delta 1.79\left(\mathrm{~s}, 3 \mathrm{H}, \mathrm{CH}_{3}\right)$, $1.91\left(\mathrm{~s}, 3 \mathrm{H}, \mathrm{CH}_{3}\right), 1.99\left(\mathrm{~s}, 3 \mathrm{H}, \mathrm{CH}_{3}\right), 2.16\left(\mathrm{~s}, 3 \mathrm{H}, \mathrm{CH}_{3}\right), 2.24(\mathrm{~s}$, $\left.3 \mathrm{H}, \mathrm{CH}_{3}\right), 2.27\left(\mathrm{~s}, 3 \mathrm{H}, \mathrm{CH}_{3}\right), 3.48(\mathrm{~s}, 2 \mathrm{H}) ;{ }^{13} \mathrm{C} \mathrm{NMR}(67.9 \mathrm{MHz}$, $\left.\mathrm{CDCl}_{3}\right) \delta 9.96,10.30,12.74(2 \mathrm{C}), 13.10,13.42,26.70,129.02$, 130.10, 131.89, 132.67, 137.50, 137.64, 139.82, 141.17; IR (KBr) $1640,1580,1440,1370,1150,1020 \mathrm{~cm}^{-1}$; MS (70 eV) m/z (\%) $280\left(\mathrm{M}^{+}, 52.9\right), 265$ (43.7). HRMS m/z C ${ }_{15} \mathrm{H}_{20} \mathrm{OS}_{2}$ : Calcd 280.0956. Found: 280.0975. Anal. Calcd for $\mathrm{C}_{15} \mathrm{H}_{20} \mathrm{OS}_{2}$ : C, 64.24; H, 7.19. Found: C, 63.93; H, 7.48.

Bis(2,4,5-trimethylthien-3-yl)methane S,S'-Dioxide (40) (110 mg, 30\%): $\mathrm{R}_{\mathrm{f}} 0.12$ (ether/MeOH 6:1); $\mathrm{mp} 182-183^{\circ} \mathrm{C}$ (from ether); ${ }^{1} \mathrm{H} N M R\left(270 \mathrm{MHz} \mathrm{CDCl}_{3}\right) \delta 1.86\left(\mathrm{~s}, 6 \mathrm{H}, 2 \mathrm{CH}_{3}\right)$, $2.16\left(\mathrm{~s}, 6 \mathrm{H}, 2 \mathrm{CH}_{3}\right), 2.19\left(\mathrm{~s}, 6 \mathrm{H}, 2 \mathrm{CH}_{3}\right), 3.35(\mathrm{~s}, 2 \mathrm{H}) ;{ }^{13} \mathrm{C} \mathrm{NMR}$ $\left(67.9 \mathrm{MHz}^{\left.-\mathrm{CDCl}_{3}\right)} \delta 10.35,10.60,12.87,26.28,35.65,136.26\right.$, 141.00, 142.72; IR (KBr) 1638, 1580, 1430, 1378, 1130, 1030 $\mathrm{cm}^{-1}$; MS (70 eV) m/z (\%) $296\left(\mathrm{M}^{+}, 6.0\right), 280$ (100). HRMS m/z $\mathrm{C}_{15} \mathrm{H}_{20} \mathrm{O}_{2} \mathrm{~S}_{2}$ : Calcd 296.0905. Found: 296.0900. Anal. Calcd for $\mathrm{C}_{15} \mathrm{H}_{20} \mathrm{O}_{2} \mathrm{~S}_{2}$ : Calcd 60.78; $\mathrm{H}, 6.80$. Found: $\mathrm{C}, 60.55 ; \mathrm{H}$, 7.08.

Bis[1,2-bis(methoxycarbonyl)-3,5,6-trimethylphenyl]methane (41). Dimethyl acetylenedicarboxylate $(380 \mathrm{mg}$, $2.68 \mathrm{mmol})$ was added to a solution of $\mathbf{4 0}(230 \mathrm{mg}, 0.78 \mathrm{mmol})$ in $\mathrm{CH}_{2} \mathrm{Cl}_{2}(15 \mathrm{~mL})$ at ambient temperature. The mixture was stirred for $6 \mathrm{~h}$. The solvent was evaporated in vacuo, and the residue was purified by column chromatography to give $\mathbf{4 1}$ (250 mg, 66\%) as colorless crystals. 41: $\mathrm{mp} 160{ }^{\circ} \mathrm{C}$ (from ether); ${ }^{1} \mathrm{H}$ NMR $\left(270 \mathrm{MHz} \mathrm{CDCl}_{3}\right) \delta 2.00\left(\mathrm{~s}, 6 \mathrm{H}, 2 \mathrm{CH}_{3}\right), 2.16$ $\left(\mathrm{s}, 6 \mathrm{H}, 2 \mathrm{CH}_{3}\right), 2.23\left(\mathrm{~s}, 6 \mathrm{H}, 2 \mathrm{CH}_{3}\right), 3.84\left(\mathrm{~s}, 6 \mathrm{H}, 2 \mathrm{COOCH}_{3}\right)$, $3.86\left(\mathrm{~s}, 6 \mathrm{H}, 2 \mathrm{COOCH}_{3}\right), 4.20(\mathrm{~s}, 2 \mathrm{H}) ;{ }^{13} \mathrm{C} \mathrm{NMR}(67.9 \mathrm{MHz}$, $\left.\mathrm{CDCl}_{3}\right) \delta 17.23,17.68,17.93,33.21,52.36(2 \mathrm{C}), 130.58,130.82$, 132.11, 132.86, 138.51, 140.77, 169.52, 169.58; IR (KBr) 1731 $(\mathrm{C}=\mathrm{O}), 1564,1438,1318,1216,1167,1032 \mathrm{~cm}^{-1}$; MS (70 eV) $\mathrm{m} / \mathrm{z}(\%) 454$ (45.6), 438 (100). Anal. Calcd for $\mathrm{C}_{27} \mathrm{H}_{32} \mathrm{O}_{8}$ : C, 66.93; H, 6.66. Found: C, 66.44; H, 6.65.

X-ray Crystallographic Analysis of 18a. $\mathrm{C}_{17} \mathrm{H}_{16} \mathrm{O}_{3} \mathrm{~S}, \mathrm{M}$ $=302.40$, monoclinic, space group $\mathrm{P} 2 \mathrm{l} / \mathrm{n}, \mathrm{a}=12.635$ (1) $\AA$, $\mathrm{b}=$ 16.936(2) $\AA, c=6.819(1) \AA, \beta=93.62(1)^{\circ}, V=1456.3 \AA^{3}, Z=$
4, $D_{c}=1.38 \mathrm{~g} / \mathrm{cm}^{3}$, monochromated $\mathrm{Cu} \mathrm{K}_{\alpha}$ radiation, $\lambda=1.541$ $84 \AA$. A colorless prism of compound 18a (from, approximate dimensions $0.50 \times 0.30 \times 0.20 \mathrm{~mm}$ ), mounted on a glass fiber in a random orientation, was used for X-ray data collection. Data were collected on an Enraf-Nonius CAD-4 diffractometer using $\omega-2 \theta$ scan at a temperature of $23 \pm 1^{\circ} \mathrm{C}$. A total of 2683 reflections were collected of which 2463 were unique. The structure was solved by direct methods (SIR 88) (34a $^{2}$ and refined by full-matrix least-squares calculations to give $R=0.045, R_{w}$ $=0.063$ for 2149 observed independent reflections $\left[\left|F_{0}^{2}\right|>\right.$ $3 \sigma\left(\mathrm{F}_{\mathrm{o}}\right)^{2}, 2^{\circ}<\Theta<65^{\circ}$ ]. All non-hydrogen atoms were located in succeeding difference $F$ ourier syntheses and anisotropically treated. Hydrogen atoms were included in the refinement but restrained to ride on the atom to which they are bonded. All calculations were performed on a MicroVAX 3100 computer using MolEN. ${ }^{35}$

X-ray Crystallographic Analysis of 24. $\mathrm{C}_{16} \mathrm{H}_{18} \mathrm{O}_{6} \mathrm{~S}, \mathrm{M}$ $=338.38$, monoclinic, space group $\mathrm{P} 2_{1 / n}, a=12.798(1) \AA, b=$ 14.012(1) $\AA, \mathrm{c}=9.017(1) \AA, \beta-91.18(1)^{\circ}, \mathrm{V}=1616.7 \AA^{3}, \mathrm{Z}=4$, $\mathrm{D}_{\mathrm{c}}=1.39 \mathrm{~g} / \mathrm{cm}^{3}$, monochromated Cu $\mathrm{K}_{\alpha}$ radiation, $\lambda=1.541$ $84 \AA$. A colorless prism of compound 24 (from ether, approximate dimensions $0.50 \times 0.40 \times 0.20 \mathrm{~mm}$ ), mounted on a glass fiber in a random orientation, was used for X-ray data collection. Data were collected on an Enraf-Nonius CAD-4 diffractometer using $\omega-2 \theta$ scan at a temperature of $23 \pm 1$ ${ }^{\circ} \mathrm{C}$. A total of 5759 reflections were collected, of which 2757 were unique. The structure was solved by direct methods (SIR $88)^{34 a}$ and refined by full-matrix least-squares cal culations to give $R=0.045, R_{w}=0.059$ for 1963 observed independent reflections $\left[\left|\mathrm{F}_{0}{ }^{2}\right|>3 \sigma\left(\mathrm{F}_{0}\right)^{2}, 2^{\circ}<\Theta<65^{\circ}\right]$. All non-hydrogen atoms were located in succeeding difference F ourier syntheses and anisotropically treated. Hydrogen atoms were included in the refinement but restrained to ride on the atom to which they are bonded. All calculations were performed on a MicroVAX 3100 computer using MolEN. ${ }^{35}$

X-ray Crystallographic Structure of 36. $\mathrm{C}_{12} \mathrm{H}_{16} \mathrm{O}_{2} \mathrm{~S}_{2}, \mathrm{M}$ $=256.34$, monodinic, space group $P 2_{1 / n}, a=11.536(2) \AA, b=$ 8.428(1) $\AA, c=11.471(3) \AA, \beta=109.35(2)^{\circ}, v=1052.3(4) \AA^{3}$, $\mathrm{Z}=4, \mathrm{D}_{\mathrm{c}}=1.441 \mathrm{~g} / \mathrm{cm}^{3}$, monochromated Cu K $\mathrm{K}_{\alpha}$ radiation, $\lambda=$ $1.54184 \AA$. A colorless prism of compound 36 (from approximate dimensions $0.30 \times 0.30 \times 0.27 \mathrm{~mm}$ ), mounted on a glass fiber in a random orientation, was used for X-ray data collection. Data were collected on an Enraf-Nonius CAD-4 diffractometer using $\omega-2 \theta$ scan at a temperature of $23 \pm 1$ ${ }^{\circ} \mathrm{C}$. A total of 3765 reflections were collected of which 3765 were unique. The structure was solved by direct methods (SIR $92)^{34 b}$ and refined by full-matrix least-squares cal culations to give $R=0.049, R_{w}=0.113$ for 1989 observed independent reflections $\left[\left|\mathrm{F}_{0}^{2}\right|>3 \sigma\left(\mathrm{F}_{0}\right)^{2}, 2^{\circ}<\Theta<65^{\circ}\right]$. All non-hydrogen atoms were located in succeeding difference F ourier syntheses and anisotropically treated. Hydrogen atoms were included in the refinement but restrained to ride on the atom to which they are bonded. All calculations were performed on an IBM RISC System/6000 380 computer using SHE LX-93. ${ }^{36}$

Supporting Information Available: NMR spectra for compounds 5, 11, 12, 16, 18b, 20, 22, 30a, 31b, 34, and 41 (25 pages). This material is contained in libraries on microfiche, immediately follows this article in the microfilm version of the journal, and can be ordered from the ACS; see any masthead page for ordering information.

\section{J O961985Z}

(34) (a) Burla, M. C.; Camalli, M.; Cascarano, G.; Giacovazzo, C.; Polidori, G.; Spagna, R.; Vitebo, D.J . Appl . Crystallogr. 1989, 22, 389393. (b) Altomare, M. C.; Burla, M.; Camalli, G.; Cascarano, C.; Giacovazzo, A.; Guagliardi, G.; Polidori, J . J . Appl. Crystallogr. 1994 27, 435.

(35) MolEN, An Interactive Structure Solution Procedure, EnrafNonius, Delft, The Netherlands, 1990.

(36) Sheldrick, G. M., SHELX-93, University of Göttingen, 1993.

(37) The author has deposited atomic coordinates for this structure with the Cambridge Crystallographic Data Centre. The coordinates can be obtained, on request, from the Director, Cambridge Crystallographic Data Centre, 12 Union Road, Cambridge, CB2 1EZ, UK. 